\title{
Immune Dysfunctions and Immune- Based Therapeutic Interventions in Chronic Lymphocytic Leukemia
}

\author{
Valentina Griggio ${ }^{1,2 t}$, Francesca Perutelli ${ }^{1,2 \dagger}$, Chiara Salvetti ${ }^{1,2}$, Elia Boccellato ${ }^{1,2}$, \\ Mario Boccadoro ${ }^{1,2}$, Candida Vitale ${ }^{1,2 \dagger \neq}$ and Marta Coscia ${ }^{1,2^{\star}+\neq}$ \\ 1 University Division of Hematology, A.O.U. Città della Salute e della Scienza di Torino, Torino, Italy, ${ }^{2}$ Department of \\ Molecular Biotechnology and Health Sciences, University of Torino, Torino, Italy
}

\section{OPEN ACCESS}

Edited by:

Jérôme Paggetti,

Luxembourg Institute of Health, Luxembourg

Reviewed by: Arnon Kater,

Amsterdam University Medical Center (UMC), Netherlands

Philipp M. Roessner,

German Cancer Research Center (DKFZ), Gemany

*Correspondence:

Marta Coscia

marta.coscia@unito.it

${ }^{\text {t}}$ These authors have contributed equally to this work

${ }^{\ddagger}$ These authors share senior authorship

Specialty section:

This article was submitted to Cancer Immunity and Immunotherapy,

a section of the journal

Frontiers in Immunology

Received: 13 August 2020

Accepted: 14 October 2020

Published: 18 November 2020

Citation:

Griggio V, Perutelli F, Salvetti $C$, Boccellato E, Boccadoro M, Vitale C and Coscia M (2020) Immune

Dysfunctions and Immune-Based

Therapeutic Interventions in Chronic Lymphocytic Leukemia.

Front. Immunol. 11:594556. doi: 10.3389/fimmu.2020.594556
Chronic lymphocytic leukemia (CLL) is a B-cell malignancy characterized by a wide range of tumor-induced alterations, which affect both the innate and adaptive arms of the immune response, and accumulate during disease progression. In recent years, the development of targeted therapies, such as the B-cell receptor signaling inhibitors and the $\mathrm{Bcl}-2$ protein inhibitor venetoclax, has dramatically changed the treatment landscape of CLL. Despite their remarkable anti-tumor activity, targeted agents have some limitations, which include the development of drug resistance mechanisms and the inferior efficacy observed in high-risk patients. Therefore, additional treatments are necessary to obtain deeper responses and overcome drug resistance. Allogeneic hematopoietic stem cell transplantation (HSCT), which exploits immune-mediated graft-versus-leukemia effect to eradicate tumor cells, currently represents the only potentially curative therapeutic option for CLL patients. However, due to its potential toxicities, HSCT can be offered only to a restricted number of younger and fit patients. The growing understanding of the complex interplay between tumor cells and the immune system, which is responsible for immune escape mechanisms and tumor progression, has paved the way for the development of novel immune-based strategies. Despite promising preclinical observations, results from pilot clinical studies exploring the safety and efficacy of novel immune-based therapies have been sometimes suboptimal in terms of long-term tumor control. Therefore, further advances to improve their efficacy are needed. In this context, possible approaches include an earlier timing of immunotherapy within the treatment sequencing, as well as the possibility to improve the efficacy of immunotherapeutic agents by administering them in combination with other anti-tumor drugs. In this review, we will provide a comprehensive overview of main immune defects affecting patients with CLL, also describing the complex networks leading to immune evasion and tumor progression. From the therapeutic standpoint, we will go through the evolution of immune-based therapeutic approaches over time, including i) agents with broad immunomodulatory effects, such as immunomodulatory drugs, ii) currently approved and next-generation monoclonal antibodies, and iii) immunotherapeutic strategies aiming at activating or administering 
immune effector cells specifically targeting leukemic cells (e.g. bi-or tri-specific antibodies, tumor vaccines, chimeric antigen receptor T cells, and checkpoint inhibitors).

Keywords: chronic lymphocytic leukemia, immune dysfunction, immunotherapy, immunomodulation, targeted therapy, cellular therapy, chimeric antigen receptor $\mathrm{T}$ cells

\section{INTRODUCTION}

Chronic lymphocytic leukemia (CLL) is a lymphoproliferative disease characterized by the clonal accumulation of mature $\mathrm{B}$ lymphocytes in the peripheral blood, bone marrow and secondary lymphoid organs (1). A hallmark of CLL is the variable clinical course, which reflects the biological heterogeneity of tumor cells. The lack of somatic mutations on immunoglobulin heavy chain variable (IGHV) genes, and/or the presence of chromosomal aberrations and genetic lesions identify patients with more aggressive forms of the disease [as reviewed in $(1,2)]$. Besides intrinsic features of the malignant clone, profound defects of the immune system and the ability of leukemic cells to circumvent immune recognition and elimination are leading causes of tumor progression. In CLL, tumor cells and cellular components of the microenvironment are reciprocally interconnected and co-evolve, shaping each other during the course of the disease [as reviewed in (3-5)].

Some immunological alterations [e.g. T-cell and natutal killer (NK)-cell expansion, and reduction of circulating normal B cells] are also associated with monoclonal B-cell lymphocytosis (MBL), a premalignant condition that precedes CLL $(6,7)$. However, most of the immune surveillance dysfunctions accumulate during disease evolution, most likely constributing to the transition from MBL to CLL [as reviewed in $(8,9)$ ]. From the clinical standpoint, these immunologic dysregulations are responsible for the increased susceptibility to infections and secondary malignancies, the occurrence of autoimmune phenomena and the failure to control disease progression (10, 11) [and as reviewed in $(5,12-17)]$.

In patients with CLL carrying favorable prognostic factors (i.e. mutated IGHV genes), the chemoimmunotherapy combination regimen consisting of fludarabine, cyclophosphamide, and rituximab (FCR) allows the achievement of undetectable minimal residual disease and long-term remissions (18). More recently, combinations including multiple targeted drugs with a different mechanism of action, such as BTK and Bcl-2 inhibitors with or without anti-CD20 monoclonal antibodies $(\mathrm{mAb})$, have shown very promising results in terms of depth and durability of response, although data are not yet mature (19-21).

Nevertheless, to date, the only therapeutic approach with a consolidated, long-term potentially curative effect is the allogeneic hematopoietic stem cell transplantation (HSCT). HSCT, which is still considered a valuable treatment option for younger and fit patients with high-risk CLL (i.e. relapsed/ refractory patients with poor prognostic features), exploits a Tcell mediated graft-versus-leukemia reaction, thus supporting the evidence that a competent immune system can be effective in controlling and eradicating the tumor. Due to the advanced median age and the high frequency of comorbidities, HSCT can be reserved only to a restricted number of patients with CLL [as reviewed in (22)]. However, other approaches exploiting immunological mechanisms, such as adoptive chimeric antigen receptor (CAR) T-cell therapy, possibly in combination with drugs showing immunomodulatory properties (e.g. lenalidomide and targeted drugs), have shown promising preclinical and/or clinical results.

In this review, we will comprehensively describe immune alterations occurring in CLL, and we will go through the evolution of immune-based therapeutic approaches over time, also addressing most recent advances in the field of immunotherapy.

\section{IMMUNE ESCAPE IN CLL}

During the clinical course, CLL cells induce a progressive impairment of the immune system leading to a state of clinically manifest immune suppression, which is in part responsible for the lack of disease control [as reviewed in $(3,4)$ ]. The association between immune deficiency and tumor progression has been widely explored in CLL. Studies report that immune defects characterizing patients since diagnosis frequently exacerbate in advanced CLL stages, and that a wide range of quantitative and qualitative alterations affect both the innate and the adaptive arms of the immune response, have been reported (as summarized in Figure 1) [as reviewed in $(5,23,24)]$. Defects in main players of innate immunity, which include cell populations of lymphoid (i.e. NK cells, NKT cells, and $\gamma \delta$ T cells) and myeloid [i.e. dendritic cells (DC) and macrophages] lineage, contribute to the ineffective triggering and maintenance of T-cell responses, as well as to their suboptimal cytotoxic activity. In the context of the adaptive immune response, several aberrations of the T-cell compartment, ranging from phenotypical changes to functional impairment, have been described [as reviewed in (24-26)]. Besides cellular components, significant alterations of the humoral response also contribute to the tumor immune escape in CLL (5). Elucidating the immune cell dysfunctions and identifying the mechanisms underlying immune suppression are crucial steps to attempt an immune system reactivation, and develop effective and novel immune-based treatment strategies.

\section{Phenotypic and Functional Alterations of the NK- and NKT-Cell Compartments}

Most studies report that NK-cell number is increased in the peripheral blood of CLL patients and associates with better prognosis (27-34). NK cells represent an appealing lymphocyte subset to be exploited in the context of immunotherapy, especially for their non-major histocompatibility complex 


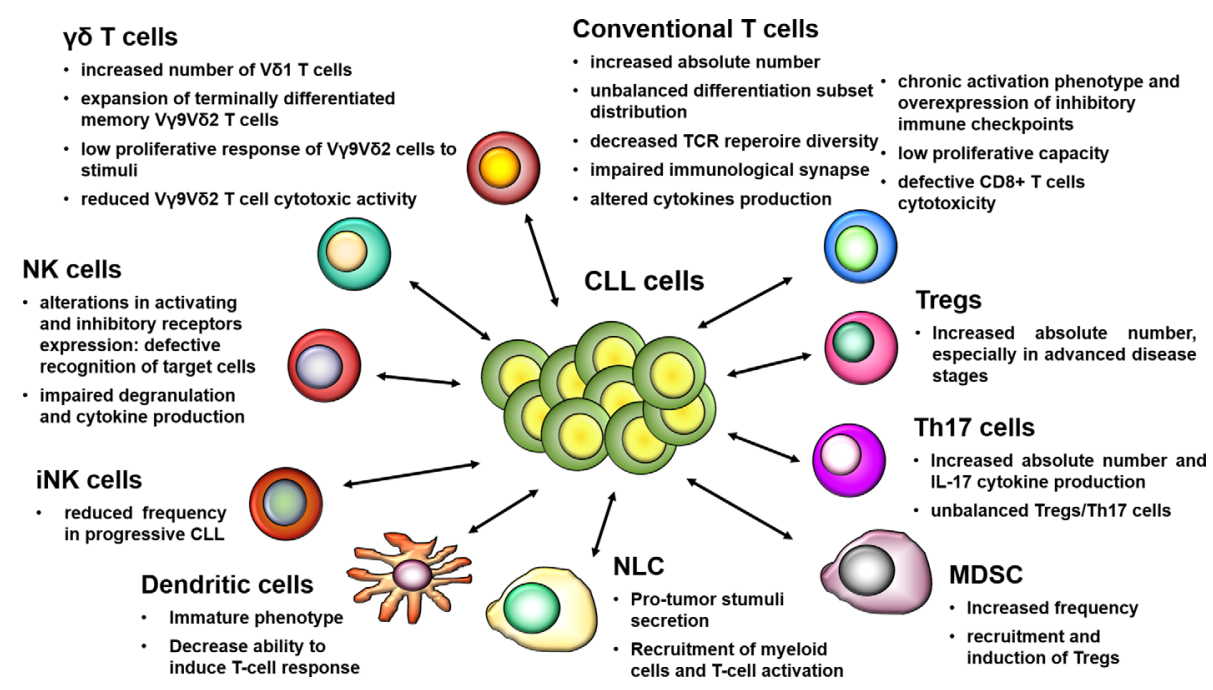

FIGURE 1 | Schematic overview of main defects affecting immune cell populations in CLL. The dysregulation of the immune response in CLL includes phenotypic alterations and functional impairments, which are present since the early stages and exacerbate during the course of the disease, thus promoting immune tolerance and tumor progression. The mutual interactions between leukemic cells and cellular elements of the immune system contribute to the establishment of a permissive or even supportive microenvironment that favors tumor progression, thus playing a key role in immune escape mechanisms.

(MHC)-restricted cytotoxicity (35). However, it has been demonstrated that autologous NK cells are not able to effectively eliminate CLL cells, because of both NK-cell intrinsic defects and immune escape mechanisms employed by tumor cells (36-41). The effector function of NK cells rely on combined signaling via a variety of activating and inhibitory receptors whose ligands are either expressed on the surface of target cells or secreted in soluble forms. Several studies focused their attention on the balance between inhibitory and activating receptors signals in CLL, and their role in regulating the final NK-cell-mediated anti-tumor response. The inhibitory receptors NKG2A and the killer-cell immunoglobulin-like receptors (KIRs), through the binding with their respective ligands HLAE and HLA-A on tumor cells, suppress cytokine secretion and hamper direct cytotoxicity of NK cells against target cells (31, 42). The expression of NKG2A is similar on NK cells from CLL patients and healthy donors, whereas its ligand HLA-E is overexpressed on the surface of leukemic cells (41-44). It has been reported that plasma levels of soluble HLA-E (sHLA-E) are higher in advanced-stage CLL patients and associate to shorter treatment free survival. In addition, sHLA-E secreted by tumor cells in vitro inhibits cell degranulation and IFN- $\gamma$ production by NK cells, thus determining their functional impairment (44). Similarly, plasma samples from CLL patients were reported to contain increased levels of soluble HLA-G, the ligand of the inhibitory receptor (KIR)2DL4, and to be capable of dampening both the viability and cytotoxic function of NK cells from healthy donors in vitro (45). HLA-G is also bound with high affinity by the Ig-like transcript 2 (ILT2) inhibitory receptor, which is overexpressed on NK cells from CLL patients (43). As an additional inhibitory mechanism, in line with data on conventional $\mathrm{T}$ cells, the immune checkpoint Tim-3 was found to be aberrantly expressed on the NK-cell compartment (28).
Concerning activating receptors, the reduced expression of NKG2D, DNAM-1 and natural cytotoxicity receptors (NCRs) reported on NK cells of CLL patients compared to healthy individuals, is paralleled by a defective cytotoxic activity, degranulation and direct killing of target cells $(28,31,32$, 41, $46,47)$. Of note, CLL cells have decreased surface level of NKG2D and NCRs ligands, which are also shed as soluble molecules (i.e. sMIC-A, sMIC-B, and sULBP2), thus contributing to a hindered recognition of tumor cells by NK cells (48-50). Notably, NK-cell dysfunctions are not permanent and can be reversed by proper stimulation with cytokines (i.e. IL2, IL-15, IL-27) $(41,51,52)$.

Despite the abnormalities reported so far, NK cells retain their ability to efficiently induce antibody-dependent cellular cytotoxicity (ADCC), through the binding of CD16 (FcyRIIIA) to the Fc-regions of antibody-antigen complexes located on the surface of tumor cells $(31,34,41,46,53)$. In CLL, ADCC has a pivotal therapeutic role because several treatment strategies include anti-CD20 $\mathrm{mAb}$, whose activity rely on this process. Due to their preserved ADCC function and the reversibility of other CLL-related dysfunctions, NK cells are therefore an attractive source for cellular immunotherapy in this disease.

Within innate immunity, another cell player with a potential anti-tumor role are type I NKT cells, also called invariant NKT (iNKT) cells. iNKT cells have the ability to activate and expand in response to antigens presented by CD1d (54-57). In CLL, little information regarding NKT cells and, specifically, iNKT cells is currently available, and mainly supports their contribution to CLL immune surveillance $(58,59)$. Interestingly, iNKT-cell frequency is significantly lower in patients with progressive disease than in patients with stable disease, and has shown to be an independent predictor of disease progression (60). Concerning the leukemic counterpart, a reduced expression of 
CD1d has been described on CLL cells compared to normal B cells from healthy donors $(58,59,61,62)$. From the functional standpoint, CLL cells have a limited ability to present glycolipid antigens to iNKT cells and to induce their expansion and functional activation $(58,63,64)$. Of note, this reduced capacity of leukemic cells to stimulate iNKT cells can be effectively reversed by retinoic acid, which upregulates the expression of CD1d on CLL cells and enhances iNKTmediated cytotoxicity against tumor targets loaded with $\alpha$ galactosylceramide (59).

\section{$\gamma \delta \mathrm{T}-$ Cell Alterations}

Among various lymphocyte subsets being considered for cellular immunotherapy of cancer are $\gamma \delta \mathrm{T}$ cells (both $\mathrm{V} \delta 1$ - and $\mathrm{V} \delta 2$ expressing $\mathrm{T}$ cells), which have the ability to mediate responses through the activation of cytotoxic mechanisms against tumor cells in a MHC-unrestricted manner (35). Patients with CLL have increased numbers of circulating $\mathrm{V} \delta 1 \mathrm{~T}$ cells which are able to produce TNF- $\alpha$ and INF- $\gamma$. Moreover, $V \delta 1 \mathrm{~T}$ cells are able to kill leukemic cells expressing the MIC-A and ULBP3 surface molecules, which are involved in the activation of $\gamma \delta \mathrm{T}$-cell effector functions through the engagement of the NKG2D receptor (65). Interestingly, preclinical studies reported that $\mathrm{V} \delta 1 \mathrm{~T}$ cells can be properly stimulated to express NCRs that act as costimulatory molecules and improve their cytotoxic activity against CLL cells both in vitro and in a xenograft mouse model $(66,67)$. In healthy subjects, the main subset of circulating $\gamma \delta \mathrm{T}$ cells is represented by $\mathrm{V} \gamma 9 \mathrm{~V} \delta 2 \mathrm{~T}$ cells, which consist of cytotoxic T lymphocytes with a putative potent antitumor activity, triggered by the MHC-independent recognition of non-peptidic phosphoantigens, such as intermediate metabolites of the mevalonate metabolic pathway and aminobisphosphonates [as reviewed in (68)]. We have previously demonstrated that in CLL the V $\gamma 9 \mathrm{~V} \delta 2 \mathrm{~T}$ cellcompartment is characterized by an unbalanced differentiation subset distribution, with a prominent expansion of effector memory and terminally differentiated effector memory cell subsets, determining a low in vitro proliferative response and predicting for a more aggressive clinical course (69). In addition, de Weerdt et al. reported that V $\gamma 9 \mathrm{~V} \delta 2 \mathrm{~T}$ cells from CLL patients are less effective in inducing tumor cell death, due to a dysfunction in effector cytokine production and degranulation. Interestingly, the observations that an altered phenotype is also inducible in healthy $\mathrm{V} \gamma 9 \mathrm{~V} \delta 2 \mathrm{~T}$ cells co-cultured with CLL cells, and that in CLL patients the functional impairment of $\mathrm{V} \gamma 9 \mathrm{~V} \delta 2 \mathrm{~T}$ cells is associated with higher leukocytes counts, indicate a leukemia-induced mechanism of immune suppression (70).

\section{Defects}

DC are specialized antigen presenting cells (APC) with a crucial role in the initiation and regulation of innate and adaptive immune responses, and whose functional modulation is under investigation with the aim of improving cancer immunotherapy. In CLL, DC show an immature phenotype (lack of CD80 and CD83 expression), and have an altered capacity to stimulate Tcell proliferation, to drive $\mathrm{T}$-cell differentiation toward $\mathrm{T}$ helper (Th) 1 response and to release IL-12 $(71,72)$. In addition, Orsini et al. reported that CLL cells are able to modify the maturation and function of healthy donor-derived DC through the secretion of IL-6 (71). Recent data demonstrated that the molecular mechanism underlying DC abnormalities in CLL is a disruption of the IL-4R/ STAT6 pathway due to enhanced levels of the suppressor of cytokine signaling 5 (SOCS5), a negative regulator that inhibits STAT6 activation and leads to a defective DC differentiation (72). Notably, despite these observed alterations, different studies and clinical trials showed that DC from CLL patients can be properly manipulated and effectively exploited in the context of vaccination approaches (73-77).

\section{Phenotypic and Functional T-Cell Alterations}

$\mathrm{T}$ lymphocytes have a fundamental role in tumor immunesurveillance. In the context of adaptive immune response, CD4+ Th cells are the main actors in antigen recognition, activation of humoral response, cytokine production, and coordination of CD8+ cytotoxic $\mathrm{T}$ lymphocyte response [as reviewed in (25, 26)]. Overall, circulating CD4+ and CD8+ T lymphocytes are increased in patients with CLL (78-80). The expansion of CD8+ T cells is prominent and results in a drop of the CD4:CD8 ratio, which characterizes CLL patients since the early phases of the disease $(79,81)$. A number of studies attributed a prognostic value to the CD4:CD8 ratio, whose inversion has been associated with advanced disease, and has shown to predict a shorter time to first treatment and overall survival (82-84). Concerning Th subset distribution, most reports agree on the accumulation of Th1 T cells in the peripheral blood of CLL patients compared to healthy controls, whereas data on Th2 T cells are still controversial (8588). From the functional standpoint, a recent article by Roessner et al. has investigated the pro- or anti-tumoral effect of Th1 T cells on CLL development, showing that the accumulation of Th1 T cells observed in human CLL and in a mice with CLL-like disease has no impact on disease progression (87). In terms of T-cell differentiation subsets distribution, a reduction in naïve $\mathrm{T}$ cells and an accumulation of effector $\mathrm{T}$ cells and highly differentiated memory $\mathrm{T}$ cells were observed in CLL patients $(82,85,89,90)$. Several evidences suggest that T lymphocytes in CLL patients are subjected to chronic antigenic stimulation, which shapes their phenotype and functional activity. Indeed, $\mathrm{T}$ cells show an increased surface expression of CD57, CD69, and HLA-DR, which are typical markers of activated cells $(91,92)$. Phenotypic and functional properties of $\mathrm{T}$ cells from patients with CLL resemble those of exhausted $\mathrm{T}$ cells, which are typically observed during chronic infections (93). Although cytomegalovirus (CMV) infection has shown to induce T-cell expansion and modulate the distribution of differentiation subsets, the exhaustion observed in $\mathrm{T}$ cells from CLL patients resulted to be independent from CMV serostatus $(82,93-95)$. The progressive skew of the T-cell receptor (TCR) repertoire occurring during disease progression, may suggest a tumor-related antigen-mediated selection $(96,97)$. In line with this observation, an oligoclonal CD8+ effector T-cell population, that expands along with CLL progression and controls disease development, was observed in both CLL patients and mice bearing a CLL-like disease (90). Consistently, through a cell-tocell-mediated mechanism, leukemic cells induce in CD4+ and 
CD8+ $\mathrm{T}$ cells purified from CLL patients several changes in the expression of genes involved in CD4+ T-cell differentiation, cytoskeleton formation, and vesicle trafficking, and in CD8+ T-cell cytotoxicity (98). These evidences confirm the contribution of the leukemic counterpart in shaping a pro-tumor microenvironment. The aberrant gene expression profile has an impact on the T-cell functions, mainly in terms of immunological synapse formation with APC, proliferation, migration, and cytotoxic activity (99102). In particular, a key regulatory mechanism of immune evasion in CLL is the impaired killing of target cells by cytotoxic $\mathrm{T}$ lymphocytes, which is associated with the formation of dysfunctional non-lytic immune synapses and to a nonpolarized release of lytic granules (101). Lastly, also metabolic features, such as mitochondrial respiration, membrane potential and levels of reactive oxygen species, have an impact on T-cell fitness, and demonstrate to be particularly relevant for CAR T-cell expansion and persistence (103).

The aberrant expression of immune checkpoint molecules, which regulate T-cell activation and function, is a hallmark of an impairment in immune surveillance. The engagement of checkpoint receptors by their ligands leads to the inhibition of $\mathrm{T}$-cell proliferation and cytokine production, thus suppressing immune responses. In CLL, both CD4+ and CD8+ T cells show an increased expression of several inhibitory checkpoints, such as CTLA-4, PD-1, LAG3, Tim-3, TIGIT, CD160, and CD244 (89, 93, 104-110). Of note, this abnormal expression of immune checkpoint receptors on $\mathrm{T}$ lymphocytes is paralleled by an increased expression of their corresponding inhibitory ligands, such as PD-L1/PD-L2, CD200, galectin-9, and CD276, on leukemic cells $(89,99,110,111)$. CTLA-4 and PD-1 are the more extensively studied immune checkpoints in CLL. T cells from CLL patients have a higher expression of both the intracellular and surface forms of CTLA-4 compared to healthy controls $(85,112)$. In addition, the upregulation of PD-1 was observed in CD4+ and CD8+ T cells from patients with CLL and was reported to associate with adverse prognosis $(82,85,89,113)$. PD-1 expression is further increased in T cells from the lymphnode compared to the peripheral blood compartment $(90,114)$. Interestingly, the double positivity for PD-1 and Tim-3 identifies a T-cell subset with a particularly pronounced impairment in the effector functions (108). Despite their features of impairment, some functional aspects of $\mathrm{T}$ cells from the peripheral blood of CLL patients, such as cytokine production, were initially reported to be preserved or even enhanced in comparison to healthy individuals (93). By contrast, CD8+ T cells from secondary lymphoid organs, which are continuously exposed to leukemic cells, express higher levels of PD-1 and are functionally defective $(90,114)$.

A better understanding of the mechanisms leading to this tumor-induced dysfunction of CD8+ T cells will be important for the development of effective T-cell-based immunotherapeutic strategies for the treatment of CLL patients.

\section{Features of Immunosuppressive Cells and of the Tolerogenic Milieu in CLL}

Multiple signals emanated by tumor cells shape the tumor supportive functions of different cellular elements of the tumor microenvironment, including stromal cells, T cells, and myeloidderived cells. In addition, extrinsic features of the tumor nichesuch as hypoxia-contribute to this tolerogenic milieu, leading to the engagement of cell subsets endowed with immune suppressive properties, such as T regulatory cells (Tregs) and myeloid-derived suppressor cells (MDSC) (115).

Several studies agree with the demonstration that circulating Tregs count is increased in CLL patients with respect to healthy controls, while data on Tregs frequency among total CD4+ T cells are not consistent (116-119). Higher Tregs number associates with increased tumor load, advanced stages of disease, disease progression, and poor prognosis $(116,117,120$, 121). Interestingly, Jak et al. reported that the expansion of Tregs in CLL can be mediated by CD27-CD70 interactions in the lymphnode and by an impaired sensitivity to apoptosis linked to a Bcl-2 overexpression, rather than being the consequence of chronic antigenic stimulation (122). In parallel to the higher number, an increased production of IL-10 and TGF- $\beta 1$, and an overexpression of the immunosuppressive molecule CTLA-4 characterize Tregs from CLL patients compared to controls $(104,121,123)$. From the functional standpoint, available information indicates that the suppressive activity of Tregs is preserved in patients with CLL (117). Indeed, Tregs i) proliferate in response to TCR stimulation, ii) display CD107a surface expression as a marker of cytotoxic activity, and iii) are able to inhibit T-cell proliferation $(120,124,125)$. In addition, a recent study has demonstrated that in CLL patients Tregs switch toward an effector-like T-cell phenotype, which is associated with an altered cytokine profile and transcriptional program of immune genes (126).

Tregs are strictly interconnected with the Th17-cell population, a subset of pro-inflammatory cells involved in the development and evolution of tissue inflammation and autoimmune diseases, and with a dichotomous role in cancer [as reviewed in (127)]. Patients with CLL have an increased frequency and absolute number of Th17 cells, and higher IL-17A and IL-17F serum levels compared to healthy controls. Of note, the Th17-cell number is associated with the presence of favorable prognostic factors, an early stage of the disease and a longer overall survival $(85,88,128-133)$. Although these evidences suggest that Th17 cells may have a protective function, their role within the CLL microenvironment is not yet fully understood. Indeed, a recent study by Zhu at el. reported that the stimulation of CLL cells and bone marrow mesenchymal stem cells with IL-17 induces the generation of IL-6, a prosurvival cytokine for tumor cells. Consistently, results obtained by in vivo experiments have demonstrated that IL-17 treatment favors CLL cells engraftment in a xenograft model through an IL6-mediated mechanism (134). Lastly, a rise in the Th17-cell count leading to an unbalanced Tregs/Th17 ratio has been found in a subset of patients who undergo autoimmune complications, suggesting a possible contribution of this cell population to the pathogenesis of CLL-related autoimmune cytopenias [as reviewed in (128)].

Another player in the tolerogenic milieu of CLL is represented by MDSC, which accumulate in the peripheral blood of CLL 
patients. MDSC are defined as CD14+/HLA-DR ${ }^{\text {low }}$ cells and are endowed with potent immunosuppressive activity, limiting the T-cell-mediated anti-tumor responses and the effectiveness of immune therapeutic approaches [as reviewed in $(135,136)]$. The frequency of MDSC associates with tumor progression and poor prognosis in CLL (137-140). Different studies provided the evidence of a complex network of interactions occurring between tumor cells, T-cell compartments, and MDSC. CLL cells enhance indoleamine 2,3-dioxygenase (IDO) gene expression in MDSC, which, in turn, suppresses in vitro T-cell activation and induces suppressive Tregs (138). On the other hand, MDSC depletion results in a control of CLL development and restores T-cell differentiation subsets skewing in the $\mathrm{E} \mu$ TCL1 mouse model, thus confirming the role of MDSC in mediating CLL-related immune dysfunctions (141). An additional mechanism by which CLL cells maintain a supportive microenvironment is the secretion of exosomes inducing PD-L1 and inflammatory cytokine expression in monocytes, thus triggering their reprogramming toward MDSC $(142,143)$.

Among cells of myeloid origin, nurse like cells (NLC) are known to generate in vitro from monocytes and to contribute to CLL cells protection from spontaneous and drug-induced apoptosis. The in vivo counterpart of NLC is represented by tumor-associated M2-polarized macrophages, typically residing in the lymphnode and bone marrow of CLL patients. NLC actively shape the microenvironment through the secretion of several cytokines and chemokines: on one hand, NLC attract tumor cells and sustain their survival and, on the other, they promote the recruitment of accessory myeloid cells and stimulate T-cell activation and proliferation $(136,144)$.

\section{Humoral Immune Response}

Up to date, there are only few data regarding the antibodymediated responses and healthy B-cell compartment in CLL, and most of them focus on immunoglobulin (Ig) deficiencies. Hypogammaglobulinemia is a very common feature and is associated with an increased risk of infections, which largely contributes to morbidity and mortality of CLL patients. At diagnosis, up to $60 \%$ of patients has decreased levels of serum Ig, with IgG, IgA, and IgM as the most affected Ig classes (145). It is well established that hypogammaglobulinemia severity correlates with advanced disease stage and worsens during progression, also correlating with shorter time to first treatment (146-148). The mechanism causing hypogammaglobulinemia is not completely clear, but it could be related to a CLL-mediated inhibition of polyclonal antibodies production and to a reduction in the number of healthy B cells $(149,150)$.

Another consequence of the altered humoral immunity is the occurrence of autoimmune complications. Episodes of autoimmune cytopenia are frequently observed in CLL patients and are attributable to high affinity polyclonal IgG autoantibodies which are produced by the non-leukemic B cells and target membrane antigens expressed on red blood cells, platelets, or granulocytes [as reviewed in $(17,151,152)$ ]. In addition, we previously reported that polyclonal antibodies directed to recurrent antigens expressed by tumor cells can be frequently found in the serum of CLL patients, especially those with progressive disease. However, these antibodies are inefficient in triggering ADCC and complement-derived cytotoxicity (CDC) (153). Alterations in the classical components of the complement cascade are reported in almost $40 \%$ of CLL patients, and contribute to the compromised CDC and to their increased susceptibility to infections $(154,155)$. Of note, complement defects may also impair the clinical efficiency of anti-CD20 mAb, which at least partially rely on CDC for their activity.

\section{IMMUNOMODULATION AND IMMUNOTHERAPY IN CLL}

The development of new targeted drugs has dramatically changed the treatment landscape of CLL. Despite their remarkable anti-tumor activity, agents like the B-cell receptor (BCR) signaling inhibitors and the Bcl-2 protein inhibitor venetoclax have some limitations, which include the development of drug resistance mechanisms and the less striking efficacy observed in patients carrying biological highrisk features [as reviewed in (156)]. The observation that allogeneic HSCT, which exploits immune-mediated graftversus-leukemia effects to eradicate tumor cells, is the only treatment option with a long-term curative potential in CLL indicates that the immune system harbors the potential for curing the disease. Therefore, treatment strategies aimed at activating or exploiting effector arms of the autologous immune system to target tumor cells have been and currently are a focus of active investigations in CLL (as summarized in Figure 2). Here, we will give an overview of immune-based strategies that are currently used or explored in patients with CLL, thereby also providing an outlook on possible future therapeutic interventions.

\section{Agents With Broad Immunomodulatory Effects}

In addition to their direct anti-tumor effect, new targeted drugs (i.e. BTK inhibitors, PI3K inhibitors, and the Bcl-2 inhibitor venetoclax) have demonstrated the ability to modulate nonneoplastic immune cell populations. PI $3 \mathrm{~K} \delta$ inhibition by idelalisib affects effector T-cell differentiation and functionality, and induces a disruption of Tregs suppressor activity, thus breaking immune tolerance both in CLL mice model and in patients $(121,124,157)$. These evidences could explain the typical immune-mediated adverse events of the drug, mainly consisting in hepatotoxicity, enterocolitis, skin rash, and pneumonitis (157-159). Notably, idelalisib has also shown to positively impact the generation of $\mathrm{T}$ cells modified to express a CAR, when added to the culture during the manufacturing process, by inducing an enrichment of less-differentiated naïvelike $\mathrm{T}$ cells, a decrease in the expression of exhaustion markers, and a normalization of the CD4:CD8 ratio (160). These data suggest the possibility of exploiting the immunomodulatory 


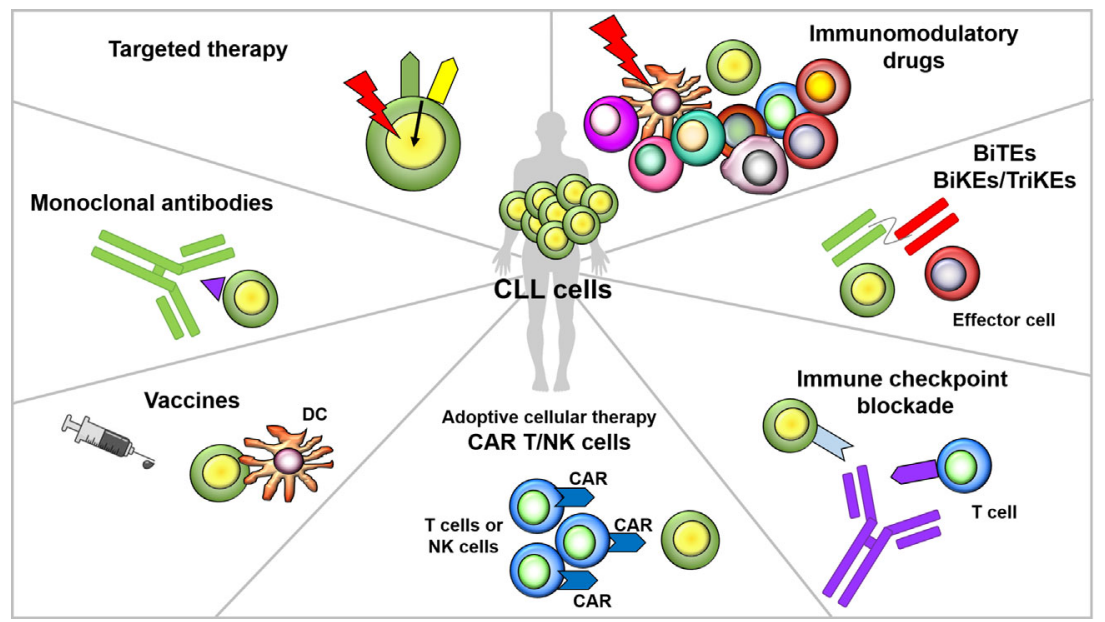

FIGURE 2 | Overview of immunomodulatory agents and immune-based strategies in CLL. Several immunotherapeutic strategies are under evaluation in CLL. Targeted drugs, in addition to a direct anti-tumor activity, can exert off-tumor immunomodulatory effects on $\mathrm{T}$ cells and other immune elements. Immunomodulatory drugs (IMiDs) exert their activity through a broad immunomodulation and pleiotropic effects on multiple elements of the immune system (e.g, T, B, NK cells and DC). Monoclonal antibodies act through the recognition of a specific antigen expressed on the surface of tumor cells, which leads to the triggering of cytotoxic responses. $\mathrm{Bi}$ - and tri-specific killer cell engagers contain two or three antigen-recognition domains, and are designed to concomitantly target a tumor cell antigen and a molecule expressed on the surface of effectors cells, with the aim of directing immune cell activity toward malignant cells. Cancer vaccines aim at inducing tumorspecific T-cell immunity in an antigen-dependent fashion, thus eliciting immunological memory and long-term protection against cancer relapse. CAR T cells are autologous T lymphocytes engineered to express a chimeric receptor, which recognizes a tumor surface antigen; upon antigen recognition and co-stimulatory domains activation, a cytotoxic response is triggered, leading to tumor cells killing. Immune checkpoint inhibitors target the interactions between co-inhibitory receptors and their ligands thus avoiding the transmission of inhibitory signals that render $\mathrm{T}$ cells functionally exhausted.

effects of idelalisib during the preparation of adoptive immunotherapies, thus avoiding the adverse effects determined by drug administration to patients.

Immune changes exerted by ibrutinib have been partially characterized in CLL. Most studies report a normalization of Tcell population counts during treatment with ibrutinib, with the exception of the paper by Long et al., which shows an increase in CD4+ and CD8+ T-cell numbers. Moreover, an increase in TCR diversity repertoire and a decrease in the expression of T-cell exhaustion markers and immune checkpoints have been observed in CLL patients receiving ibrutinib (161-169). From the functional standpoint, preclinical data did not demonstrate a beneficial effect of ibrutinib on T cells (170). However ibrutinibtreated patients showed increased response rates to CAR T cells, thus supporting the potential benefit of combination strategies $(171,172)$. The immunomodulatory activity of ibrutinib is at least partially attributable to its off-target effects on tyrosine kinases other than BTK, such as the IL-2 inducible kinase (ITK), which is mainly expressed by T cells (173). However, at this stage, it is not completely elucidated whether ibrutinib immunomodulation is also connected to the reduction of tumor burden and to the suppression of tumor-microenvironment interactions, occurring during patients treatment. In line with this latter hypothesis is the observation that also secondgeneration BTK inhibitors (i.e. acalabrutinib and zanubrutinib), despite their higher selectivity and reduced off-target effects, still show some immunomodulatory properties $(165,174)$. Consistently, immune changes occurring during venetoclax treatment may be at least partially connected to a clinical response to therapy, driving the attenuation of leukemiainduced immune alterations. In particular, venetoclax has demonstrated to i) normalize $\mathrm{B}, \mathrm{T}$, and NK-cell count, ii) decrese the percentage of tumor-supportive T-cell subsets, iii) reduce the frequency of PD-1+ CD8+ T cells, and iv) impair NKcell activation in CLL patients (114). Recent data also showed that venetoclax increases the anti-tumor effects of T-cell-based therapy against B-cell lines in vitro and in solid tumor-bearing mice model $(175,176)$.

Immunomodulatory drugs (IMiDs) have also been-and currently are-under evaluation for their anti-tumor effects in CLL. In the past 15 years, several clinical trials enrolling CLL patients have demonstrated the clinical efficacy of lenalidomide (Table 1), but have also highlighted its unique toxicity profile and a rate of adverse events that suggests caution in incorporating this agent in treatment strategies [as reviewed in (195)]. One aspect of lenalidomide that has been considered worth of investigation consists in its pleiotropic effects on the immune system. In fact, in spite of the absence of a direct in vitro cytotoxicity toward CLL cells, lenalidomide is able to favor the immune recognition of leukemic cells-through the upregulation of surface ligands and receptors-and to induce an indirect anti-tumor activity through the immunostimulation of DC as well as T, B, and NK cells. CLL patients treated with lenalidomide have a restored $\mathrm{T}$-cell function, especially in terms of Th1-type cytokine release (IL-2, IFN- $\gamma$, TNF- $\alpha$, IL-21), and formation of functional immune synapses $(99,155)$. In addition, 
TABLE 1 | Clinical trials evaluating the efficacy and toxicity of lenalidomide, used as a single agent or in combination regimens, for the treatment of patients with CLL.

\begin{tabular}{|c|c|c|c|c|}
\hline Drug regimen & Setting & Efficacy & Toxicities & References \\
\hline $\begin{array}{l}\text { Lenalidomide single agent } \\
\text { days } 1-21 \text { of } 28 \text {-day } \\
\text { cycles }\end{array}$ & $\begin{array}{l}\text { Phase II } \\
45 \text { patients R/R CLL }\end{array}$ & $\begin{array}{l}\text { ORR } 47 \% \\
\text { 9\% CR } \\
\text { 1-year PFS 81\% }\end{array}$ & $\begin{array}{l}G \geq 3 \text { neutropenia } 70 \% \\
G \geq 3 \text { thrombocytopenia } 45 \% \\
G \geq 3 \text { anemia } 18 \% \\
G \geq 3 \text { infections } 5 \% \\
G \geq 3 \text { febrile neutropenia } 15 \% \\
\text { Fatigue } 73 \% \\
\text { Tumor flare reaction } 58 \% \\
\text { TLS 5\% }\end{array}$ & $\begin{array}{l}\text { Chanan-Khan et al. } \\
(177)\end{array}$ \\
\hline $\begin{array}{l}\text { Lenalidomide single agent } \\
\text { continuously }\end{array}$ & $\begin{array}{l}\text { Phase II } \\
44 \text { patients R/R CLL }\end{array}$ & $\begin{array}{l}\text { ORR } 32 \% \\
7 \% \text { CR } \\
\text { 14-month OS } 73 \%\end{array}$ & $\begin{array}{l}\mathrm{G} \geq 3 \text { neutropenia } 41 \% \\
\mathrm{G} \geq 3 \text { thrombocytopenia 15\% } \\
\mathrm{G} \geq 3 \text { anemia } 3 \% \\
\mathrm{G} \geq 3 \text { infections } 6 \%\end{array}$ & $\begin{array}{l}\text { Ferrajoli et al. (178) } \\
\text { NCT00267059 }\end{array}$ \\
\hline $\begin{array}{l}\text { Lenalidomide single agent } \\
\text { days } 1-21 \text { of } 28 \text {-day } \\
\text { cycles }\end{array}$ & $\begin{array}{l}\text { Phase II } \\
25 \text { patients } \\
\text { Previously untreated CLL }\end{array}$ & $\begin{array}{l}\text { ORR } 56 \% \\
\text { 0 CR } \\
\text { 2-year OS } 92 \% \\
\text { PFS } 89 \%\end{array}$ & $\begin{array}{l}\mathrm{G} \geq 3 \text { neutropenia } 72 \% \\
\mathrm{G} \geq 3 \text { thrombocytopenia } 28 \% \\
\text { Tumor flare reaction } 88 \% \\
\text { Fatigue } 72 \% \\
\text { Infections } 60 \% \\
\text { Rash } 64 \%\end{array}$ & Chen et al. (179) \\
\hline $\begin{array}{l}\text { Lenalidomide single agent } \\
\text { continuously }\end{array}$ & $\begin{array}{l}\text { Phase II } \\
60 \text { elderly patients } \\
\text { Previously untreated CLL/SLL }\end{array}$ & $\begin{array}{l}\text { ORR 65\% } \\
\text { 10\% CR } \\
\text { 2-year PFS 60\% } \\
\text { 2-year OS 88\% }\end{array}$ & $\begin{array}{l}G \geq 3 \text { neutropenia } 73 \% \\
G \geq 3 \text { thrombocytopenia } 34 \% \\
G \geq 3 \text { anemia } 15 \% \\
G \geq 3 \text { infections } 10 \% \\
\text { Tumor flare reaction } 27 \%\end{array}$ & $\begin{array}{l}\text { Badoux et al. (180) } \\
\text { NCT00535873 }\end{array}$ \\
\hline $\begin{array}{l}\text { Lenalidomide single agent } \\
\text { continuously (different } \\
\text { starting doses) }\end{array}$ & $\begin{array}{l}\text { Phase II } \\
103 \text { patients } \\
\text { R/R CLL }\end{array}$ & $\begin{array}{l}\text { ORR } 40 \% \\
\text { 8\% CR; median PFS } 9.7 \text { months } \\
\text { Median OS } 33 \text { months }\end{array}$ & $\begin{array}{l}G \geq 3 \text { neutropenia } 77 \% \\
G \geq 3 \text { thrombocytopenia } 48 \% \\
G \geq 3 \text { anemia } 4 \% \\
G \geq 3 \text { infections } 41 \% \\
\text { Embolism } 6 \% \\
\text { TLS 3\% }\end{array}$ & $\begin{array}{l}\text { Wendtner et al. (181) } \\
\text { NCT00419250 }\end{array}$ \\
\hline $\begin{array}{l}\text { Lenalidomide single agent } \\
\text { continuously }\end{array}$ & $\begin{array}{l}\text { Phase III } \\
225 \text { elderly patients } \\
\text { Previously untreated CLL }\end{array}$ & $\begin{array}{l}\text { ORR } 55 \% \\
\text { 3\% CR } \\
\text { Median PFS } 30.8 \text { months }\end{array}$ & $\begin{array}{l}\mathrm{G} \geq 3 \text { neutropenia } 49 \% \\
\mathrm{G} \geq 3 \text { thrombocytopenia 25\% } \\
\mathrm{G} \geq 3 \text { anemia } 7 \% \\
\mathrm{G} \geq 3 \text { infections } 9 \% \\
\text { Tumor flare reaction } 52 \% \\
\text { Rash } 50 \%\end{array}$ & $\begin{array}{l}\text { Chanan-Khan et al. } \\
(182) \\
\text { NCT00910910 }\end{array}$ \\
\hline $\begin{array}{l}\text { Lenalidomide and } \\
\text { rituximab }\end{array}$ & $\begin{array}{l}\text { Phase II } \\
59 \text { patients } \\
\text { R/R CLL }\end{array}$ & $\begin{array}{l}\text { ORR } 66 \% \\
12 \% \text { CR } \\
\text { Median TTF } 17.4 \text { months } \\
\text { 3-year OS } 71 \%\end{array}$ & $\begin{array}{l}G \geq 3 \text { neutropenia } 73 \% \\
G \geq 3 \text { thrombocytopenia 34\% } \\
G \geq 3 \text { anemia } 15 \% \\
G \geq 3 \text { infections } 15 \% \\
\text { Neutropenic fever } 10 \%\end{array}$ & $\begin{array}{l}\text { Badoux et al. (183) } \\
\text { NCT00759603 }\end{array}$ \\
\hline $\begin{array}{l}\text { Lenalidomide and } \\
\text { rituximab }\end{array}$ & $\begin{array}{l}\text { Phase II } \\
69 \text { patients } \\
\text { Previously untreated CLL }\end{array}$ & $\begin{array}{l}\text { ORR } 87 \% \\
\text { 14\% CR } \\
\text { Median PFS: 19-20 months }\end{array}$ & $\begin{array}{l}\mathrm{G} \geq 3 \text { neutropenia } 58 \% \\
\text { Tumor flare } 75 \% \\
\text { Fatigue } 74 \% \\
\text { Transaminitis } 65 \% \\
\text { Rash } 61 \%\end{array}$ & $\begin{array}{l}\text { James et al. (184) } \\
\text { NCT00628238 }\end{array}$ \\
\hline $\begin{array}{l}\text { Lenalidomide and } \\
\text { rituximab }\end{array}$ & $\begin{array}{l}\text { Phase ॥ } \\
61 \text { previously } \\
\text { untreated + } 59 \text { R/R CLL }\end{array}$ & $\begin{array}{l}\text { Previously untreated: ORR 73\%; 35\% CR; } \\
\text { median PFS } 50 \text { months } \\
\text { R/R: ORR 64\%; } 28 \% \text { CR; median PFS } 28 \\
\text { months }\end{array}$ & $\begin{array}{l}G \geq 3 \text { neutropenia } 53 \% \\
G \geq 3 \text { thrombocytopenia } 23 \% \\
G \geq 3 \text { anemia } 13 \% \\
G \geq 3 \text { infections } 27 \% \\
G \geq 3 \text { cardiovascular } 10 \% \\
\text { Second primary tumors } 5 \%\end{array}$ & $\begin{array}{l}\text { Strati et al. (185) } \\
\text { NCT01446133 }\end{array}$ \\
\hline $\begin{array}{l}\text { Lenalidomide and } \\
\text { ofatumumab }\end{array}$ & $\begin{array}{l}\text { Phase II } \\
21 \text { patients } \\
\text { R/R CLL }\end{array}$ & $\begin{array}{l}\text { ORR } 48 \% \\
\text { O CR } \\
\text { Median OS } 21.5 \text { months }\end{array}$ & $\begin{array}{l}\mathrm{G} \geq 3 \text { neutropenia } 47 \% \\
\mathrm{G} \geq 3 \text { thrombocytopenia } 71 \% \\
\text { Fatigue } 52 \% \\
\text { Tumor flare reaction } 43 \%\end{array}$ & $\begin{array}{l}\text { Costa et al. (186) } \\
\text { NCT01123356 }\end{array}$ \\
\hline
\end{tabular}


TABLE 1 | Continued

\begin{tabular}{|c|c|c|c|c|}
\hline Drug regimen & Setting & Efficacy & Toxicities & References \\
\hline $\begin{array}{l}\text { Lenalidomide, rituximab } \\
\text { and fludarabine }\end{array}$ & $\begin{array}{l}\text { Phase I } \\
9 \text { patients } \\
\text { Previously untreated CLL }\end{array}$ & $\begin{array}{l}\text { ORR 56\% } \\
11 \% \text { CR }\end{array}$ & $\begin{array}{l}78 \% \text { of patients stopped therapy } \\
\text { because of toxicity } \\
\text { ( } 44 \% \text { hematological toxicity) }\end{array}$ & Brown et al. (188) \\
\hline $\begin{array}{l}\text { Lenalidomide, rituximab } \\
\text { and bendamustine }\end{array}$ & $\begin{array}{l}\text { Phase } I-\| \\
22 \text { patients } \\
\text { Previously untreated and } R / R \\
\text { CLL }\end{array}$ & $\begin{array}{l}\text { ORR } 50 \% \\
\text { O CR } \\
\text { Median PFS } 8 \text { months }\end{array}$ & $\begin{array}{l}95 \% \text { of patients had at least one } \\
\mathrm{G} \geq 3 \text { adverse event } \\
\mathrm{G} \geq 3 \text { neutropenia } 71 \% \\
\mathrm{G} \geq 3 \text { thrombocytopenia } 19 \% \\
\mathrm{G} \geq 3 \text { anemia } 5 \% \\
\mathrm{G} \geq 3 \text { infections } 47 \%\end{array}$ & $\begin{array}{l}\text { Maurer et al. (189) } \\
\text { NCT01558167 }\end{array}$ \\
\hline $\begin{array}{l}\text { Lenalidomide, rituximab } \\
\text { and ibrutinib }\end{array}$ & $\begin{array}{l}\text { Phase I } \\
12 \text { patients } \\
\text { R/R CLL }\end{array}$ & $\begin{array}{l}\text { ORR } 67 \% \\
8 \% \text { CR } \\
1 \text {-year PFS 78\% }\end{array}$ & $\begin{array}{l}\mathrm{G} \geq 3 \text { neutropenia } 67 \% \\
\text { Diarrhea } 58 \% \\
\text { Myalgia/arthralgia } 58 \% \\
\text { Rash } 42 \% \\
\mathrm{G} \geq 3 \text { infections } 25 \% \\
\end{array}$ & $\begin{array}{l}\text { Ujjani et al. (191) } \\
\text { NCT02200848 }\end{array}$ \\
\hline $\begin{array}{l}\text { Lenalidomide, rituximab } \\
\text { and chlorambucil, followed } \\
\text { by lenalidomide } \\
\text { consolidation }\end{array}$ & $\begin{array}{l}\text { Phase I-II } \\
63 \text { elderly or unfit patients } \\
\text { Previously untreated CLL }\end{array}$ & $\begin{array}{l}\text { ORR after induction 83\% (0 CR) } \\
\text { ORR after consolidation 93\% (14\% CR) } \\
\text { 2-year PFS 58\% }\end{array}$ & $\begin{array}{l}\text { During induction: } \\
G \geq 3 \text { neutropenia } 73 \% \\
G \geq 3 \text { thrombocytopenia 15\% } \\
\text { Rash } 11 \% \\
G \geq 3 \text { infections 9\% }\end{array}$ & $\begin{array}{l}\text { Kater et al. (192) } \\
\text { EudraCT 2010- } \\
\text { 022294-34 }\end{array}$ \\
\hline
\end{tabular}

CLL, chronic lymphocytic leukemia; $C R$, complete response; $G \geq 3$, grade $\geq 3$; ORR, overall response rate; OS, overall survival; PFS, progression free survival; $R / R$, relapsed or refractory; SLL, small lymphocytic lymphoma; TLS, tumor lysis syndrome; TTF, time to treatment failure.

lenalidomide induces wide-range immunomodulatory effects on different immune cell compartments, among which i) a decrease in Tregs count, ii) an increase in Th17 cell number, iii) an upregulation of the NKG2D activating receptor on NK cells, and iv) a rise in Ig production by normal polyclonal B cells. Besides the immune system re-education, treatment with lenalidomide also modulates interactions of CLL cells with NLC and stromal cells within the tumor microenvironment (155) [and reviewed in (195, 196)].

Compounds showing the same potent immunomodulatory effects as lenalidomide but characterized by a more manageable safety profile could represent an interesting therapeutic option for patients with CLL. Avadomide (CC-122) is a novel orally available pleiotropic pathway modulator, which has demonstrated enhanced anti-proliferative activities compared to lenalidomide, as well as the ability of eliciting anti-tumor $\mathrm{T}$ cell-mediated immune responses when combined with checkpoint inhibitors in preclinical models of CLL $(197,198)$. Based on these observations, a phase I/II clinical trial is currently evaluating the combination of avadomide plus ibrutinib or avadomide plus obinutuzumab in patients with CLL (NCT02406742).

\section{Monoclonal Antibodies}

The targeting of tumor surface antigens with $\mathrm{mAb}$ has been the first form of immunotherapy broadly applied in the treatment of CLL. CD20, a transmembrane protein typically expressed on the B-cell surface, represents an ideal target for antibody-based therapy, and its targeting currently provides the best clinical results obtained with $\mathrm{mAb}$ therapy in CLL. Rituximab, which was approved by Food and Drug Administration (FDA) in 1998, 
is a chimeric mouse-human anti-CD20 mAb. The anti-tumor activity of rituximab is exerted through CDC and ADCC mechanisms, but is limited by the low-level of expression of the CD20 antigen on the surface of CLL cells, by the presence of circulating shed CD20 antigen interfering with the binding of the $\mathrm{mAb}$ to leukemic cells and by the selection of antigen loss variants in rituximab-treated patients (199-201). Based on its poor efficacy when used as a single agent, rituximab is mainly used in combination with other drugs for the treatment of CLL patients (202). Rituximab has demonstrated to improve the efficacy of chemotherapy agents, and the combinations FCR and bendamustine plus rituximab (BR) have been validated in phase III randomized clinical trials as the standard therapy for previously untreated, fit patients without TP53 abnormalities (203-205). However, their use in the frontline setting has been recently challenged by studies comparing chemoimmunotherapy with targeted drugs, used alone or in combinations with rituximab, especially for the treatment of high-risk patients carrying unmutated IGHV and/or del(11q) (206, 207).

Next-generation anti-CD20 mAb with enhanced cytotoxic functions have later been developed. Ofatumumab is an example of type I (or rituximab-like) mAb, that mainly induces tumor cell lysis through CDC and ADCC [as reviewed in $(208,209)$ ]. Obinutuzumab is a type II anti-CD20 mAb (i.e. inducing cytotoxicity mainly through programmed cell death and ADCC) characterized by an engineered structure that allows an increased recruitment of effector cells, a potentiated ADCC and a more efficient NK cell degranulation (210). Ofatumumab and obinutuzumab have shown efficacy in phase II and/or phase III clinical trials when used in combination with conventional chemotherapy $(211,212)$, BCR inhibitors (213-215), or venetoclax (216). More recently, ublituximab, another type I anti-CD20 $\mathrm{mAb}$, has demonstrated clinical efficacy in CLL patients when administered alone or in combination with chemotherapy or targeted agents (217-219).

Other targets have been or currently are under evaluation for mAb-based therapeutic strategies in CLL. Among them, CD19 is particularly interesting, being a pan-B lymphocyte surface receptor, which is not expressed by hematopoietic stem cells and other immune cells, except for follicular DC [as reviewed in (220)]. CD19 is ubiquitously expressed on CLL cells and currently, results for two different anti-CD19 mAb evaluated in phase I studies are available. Tafasitamab is an anti-CD19 mAb with an engineered Fc region to enhance CD16 binding affinity, whereas inebilizumab is an affinity-optimized anti-CD19 mAb that enacts malignant clone elimination via ADCC. Both drugs have demonstrated safety and preliminary efficacy in previously treated CLL patients $(221,222)$. Tafasitamab containing regimens are currently under evaluation in two different phase II clinical trials enrolling patients with CLL (tafasitamab in combination with lenalidomide in the NCT02005289 trial and in combination with idelalisib or venetoclax in the NCT02639910 trial).

An additional target currently under investigation for CLL immunotherapy is CD37. CD37 is broadly and selectively expressed on tumor cells from B-cell malignancies, including CLL cells, where it is involved in various biological processes such as cell adhesion, proliferation, survival, and trafficking [as reviewed in (223)]. Otlertuzumab is an anti-CD37 fusion protein obtained from a chimeric protein (SMIP-016) and engineered to exhibit the full binding activity of an anti-CD37 mAb at onethird of the regular antibody size. The mechanism of action of otlertuzumab consists in the triggering of a direct pro-apoptotic effect and in the induction of ADCC, while sparing the activation of the complement system (224). Single-agent otlertuzumab has demonstrated a modest activity and an acceptable safety profile in a phase I study enrolling treatment-naïve and pre-treated CLL patients (225). In a following phase II trial, the same molecule in combination with bendamustine significantly increased the response rate and prolonged the progression free survival over single agent bendamustine in patients with relapsed or refractory CLL (226). An additional anti-CD37 $\mathrm{mAb}$ is BI 836826, which has been Fc-engineered to improve ADCC activity. In a phase I study it has shown an acceptable tolerability and a notable efficacy, being especially active in CLL patients with del(17p) and/or TP53 mutations (227). BI 836826 is currently under evaluation for its safety and tolerability when given in combination with ibrutinib to patients with relapsed/refractory CLL (NCT02759016).

The ideal targets for a successful anti-tumor immunotherapy are tumor associated antigens (TAA), which are molecules with a unique or highly preferential expression on malignant cells and with a crucial role for the growth and survival of the tumor. In this context, the receptor tyrosine kinase-like orphan receptor 1 (ROR1) can be considered a putative TAA for CLL, being a cancer stem cell antigen almost exclusively expressed on tumor cells and involved in the biology and aggressiveness of the disease (228). Several immune-based strategies targeting ROR1 are currently being investigated, including mAb. Cirmtuzumab, an anti-ROR1 mAb, has demonstrated to be well tolerated and effective at inhibiting ROR1 signaling in a phase I study enrolling patients with progressive, refractory, and relapsed CLL (229), and is currently under evaluation for its safety and efficacy when given in combination with ibrutinib in patients with B-cell lymphoid malignancies in a phase Ib/II protocol (NCT03088878).

\section{Bi-Specific Antibodies and $\mathrm{Bi}-$ and Tri- Specific Killer Cell Engagers}

Bi-specific antibodies (bsAb) combine specificities of two antibodies simultaneously, addressing different antigens or epitopes on the cell surface, and include a large family of molecules with different formats. Among bsAb, bi-specific $\mathrm{T}$ cells engagers (BiTEs) and bi- or tri- specific killer engagers (BiKE or TriKE) are dual or triple targeting antibodies, which act by simultaneously binding tumor antigens and effector cells ( $\mathrm{T}$ cells or NK cells), thus leading to the creation of a new immunological synapse and the triggering of cytotoxic responses. Of note, TriKEs recognize two different antigens on tumor targets allowing the binding of cancer cells even when one antigen is lost, and thus avoiding the occurrence of escape variants [as reviewed in (230-232)].

Blinatumomab, a CD19/CD3 bsAb designed in the BiTE format, was the first bsAb studied in setting of CLL patients. 
In B-cell acute lymphoblastic leukemia (B-ALL), where it is currently approved for the treatment of patients with a relapsed/refractory disease or not achieving an undetectable minimal residual disease, blinatumomab has shown a good anti-leukemic activity associated with a low treatment-related mortality (233). Blinatumomab has demonstrated to effectively kill CLL cells in vitro, through the induction of proliferation, cytokine production and granzyme B secretion in autologous $\mathrm{T}$ cells. As demonstrated by Wong et al., the formation of immunological synapses between T cells and CLL cells induced in vitro by blinatumomab indicates that this CD19/CD3 BiTE is able to overcome the T-cell dysfunction frequently observed in CLL patients (234). In preclinical studies, blinatumomab induced cytotoxicity against tumor cells at very low T-cell:tumor cell ratios, in samples from both treatment-naïve and treated patients, and also in the presence of pro-survival signals (234). A phase I study has demonstrated the feasibility of blinatumomab in relapsed/refractory B-cell non-Hodgkin lymphomas, including small lymphocytic lymphoma (235), and a clinical trial is currently testing the association between lenalidomide and blinatumomab in the same clinical setting (NCT02568553). However, specific data on the tolerability and efficacy of blinatumomab in the CLL patient population are not available.

The main limitation to the efficacy of BiTE constructs is their short half-life that requires these drugs to be administered continuously. To overcome structural limitations of BiTEs, and specifically their poor stability, next-generation bsAb with a more favorable pharmacokinetic profile are currently under investigation. To this aim, a new bsAb platform represented by dual affinity re-targeting (DART) molecules was developed. The MGD011 CD3xCD19 DART (also known as JNJ-64052781) has demonstrated a good in vitro efficacy in killing CLL cells by recruiting CLL-derived T cells against the tumor. MGD011 has shown the ability to induce activation and proliferation of $\mathrm{T}$ cells from CLL patients, and to promote a partial restore of their immunological disfunctions. Interestingly, MGD011 is also able to kill venetoclax-resistant CLL cells, through a mechanisms that is independent from Bcl-2-mediated apoptosis $(236,237)$.

Another recently-developed CD19/CD3 bsAb, designed in the single-chain Fv-Fc format (CD19/CD3-scFv-Fc), has shown to induce a particularly rapid killing of CLL cells isolated from ibrutinib-treated patients, including those with acquired ibrutinib-resistance (238).

Although not fully understood, this increased cytotoxicity seems at least in part attributable to an improved performance of $\mathrm{T}$ cells isolated from patients treated with ibrutinib. Consistently, a BiTE targeting ROR1 has shown an enhanced cytotoxic activity against primary leukemic cells when used in the presence of $\mathrm{T}$ cells isolated from ibrutinib-treated CLL patients (239). Therefore, all these data highlight the importance of the reversal of CLL-related T-cell impairment to improve the BiTE activity.

Another strategy to bypass the T-cell impairment is to exploit engagers designed to target the activity of effector cells of the innate immune system. To date, in CLL, BiKEs and TriKEs engaging NK cells have been exclusively studied in the preclinical setting, but available data encourage their potential translation to the clinic. The therapeutic potential of a CD16/CD19 BiKE and a CD16/CD19/CD22 TriKE has already been demonstrated in a preclinical study showing their ability to trigger NK cell functions in terms of cytokine and chemokine production, secretion of lytic granules and induction of tumor cell death (240). TriKEs recognizing the NKG2D receptor ligand ULBP2 (ULBP2/aCD19/aCD19 and ULBP2/aCD19/aCD33 TriKEs) have also been used to activate NK cells and showed a superior in vitro and in vivo anti-tumor activity against CLL compared to the bi-specific counterparts (201).

\section{Tumor Vaccines}

The ultimate goal of a cancer vaccine is the activation and expansion of cytotoxic $\mathrm{T}$ lymphocytes against tumor targets, thus promoting the elimination of the tumor and inducing a long-term protection against possible relapses. In CLL, the main obstacles for the production of effective tumor vaccines are the difficulty in the selection of an ideal TAA, which should be specific for the tumor but broadly expressed in the patients population, and the presence of immune dysfunctions limiting the triggering of effective and peristent anti-tumor responses.

To overcome the difficulties connected to the identification of an optimal TAA, vaccine formulations consisting of autologous whole tumor cells genetically modified to express cytokines or costimulatory molecules have been tested. The manipulation of autologous CLL cells to express a functional ligand for the CD40 molecule (i.e. CD40L or CD154) has shown to upregulate costimulatory factors on leukemic cells and to induce the generation of cytotoxic $\mathrm{T}$ lymphocytes capable of specifically recognizing parental non-modified leukemic cells in vitro (241). Based on these preclinical results, Wierda et al. have designed a phase I study to explore the clinical efficacy of a cancer vaccine consisting of autologous CLL cells genetically modified to express a human form of the CD40L molecule. Results from this study demonstrated that this vaccine formulation is well tolerated, has biological and clinical activity, and may enhance the susceptibility of CLL cells with $\operatorname{del}(17 p)$ to subsequent chemoimmunotherapy (242). Interestingly, the preclinical use of genetically modified CD40L-expressing CLL cells in combination with IL-2- or OX40L-expressing CLL cells has shown to produce an even more pronounced T-cell activation and trigger therapeutically significant leukemia-specific immune responses $(243,244)$. Despite the encouraging preliminary results, all the tested tumor cell-based vaccine formulations failed to produce reproducible clinical effects, mainly due to the existence of immune escape mechanisms and deep CLLdriven defects in the immune system. One approach aiming at restoring the immune competence of CLL patients is the use of checkpoint-blockade inhibitors to "release" the immune system to target cancer cells. In this context, the use of a tumor vaccine consisting of irradiated autologous tumor cells coated with an antibody targeting the CD200 immunoregulatory molecule has shown to be effective in a xenogenic model of CLL (245). 
An alternative strategy to induce effective anti-tumor responses is the use of vaccine formulations exploiting the antigen presentation ability of DC. The feasibility and safety of a vaccine consisting of DC loaded with apoptotic bodies derived from autologous CLL cells has already been demonstrated in an early-phase clinical trial (74). The lack of meaningful clinical effects, in this as in most other CLL vaccination trials, illustrates the need to identify more potent immune adjuvants for CLL. To this aim, lenalidomide, administered in combination with a DC vaccine, has shown its ability to elicit tumor-specific T-cells responses, although in the presence of relevant autoimmune compications that suggest caution in further exploring this drug as an immune adjuvant in CLL (75).

\section{Cellular Immunotherapy and CAR T Cells}

Adoptive cellular immunotherapy is an alternative approach to exploit the immune system to fight tumors, and consists in the isolation and expansion of effector cells that are then transferred to patients.

NK cells and $\gamma \delta$ T cells are particularly appealing candidates for cellular immunotherapy, thanks to their peculiar ability of recognizing and targeting tumor cells in an MHC unrestricted manner, which favors the induction of effective allogeneic and autologous anti-tumor responses [as reviewed in (246-248)]. In the setting of CLL, Almeida et al. designed a protocol for the clinical grade expansion and the preclinical testing of cytotoxic $\mathrm{V} \delta 1+\mathrm{T}$ cells, named Delta One T (DOT) cells. DOT cells express NCRs, which synergize with the TCR to mediate leukemic cell targeting in vitro, and inhibit tumor growth in xenograft models of CLL (67).

Immune effector cells may also be genetically engineered with the aim of improving and specifically directing their killing properties against the tumor. CAR $\mathrm{T}$ cells have been under development for more than 30 years (249), and recently entered the therapeutic armamentarium for lymphoproliferative diseases [as reviewed in (250-252)]. Anti-CD19 CAR T cells are currently approved by FDA and European Medicine Agency for the treatment of patients with aggressive B-cell lymphomas or BALL. In other hematological malignancies, including CLL, several challenges still need to be overcome for successful application of CAR T-cell therapies, including identifying alternative or additional target antigens and reversing repressive tumor microenvironments that hamper CAR T-cell function.

Novel CAR constructs that target antigens other than CD19 (e.g. CD20, CD22, ROR1) or that concomitantly target more than one antigen (e.g. CD19 and CD20, CD19 and CD22) are currently under evaluation in early phase clinical studies. Clinical trials evaluating CAR-based cellular therapies in patients with CLL are listed in Tables 2 and 3.

In spite of a safety profile not dissimilar to that observed in the setting of other lymphoproliferative diseases, which includes cytokine release syndrome (CRS) and CAR T cellrelated encephalopathy syndrome (CRES) as major complications, to date, the efficacy results of CAR T cells in CLL have been relatively discouraging, mainly due to T-cell alterations paralleling disease evolution and hampering effective anti-tumor functions of autologous CAR $\mathrm{T}$ cells.
Fraietta et al. demonstrated that the composition of the cellular product and the intrinsic T-cell functional fitness may have an impact on the therapeutic efficacy of CAR T cells in CLL. They showed that the ability of CAR T cells to expand during the manufacturing process is a predictor of response and correlates with in vivo proliferation, which is in turn responsible for a sustained anti-tumor activity. In addition to that, they observed that CAR T cells derived from patients who respond to the treatment are enriched in memory-cell lymphocytes, with enhancement of IL-6/STAT3 signals and STAT3-related cytokine production, whereas CAR T cells from patients who do not respond upregulate genetic programs involved in effector differentiation, glycolysis, exhaustion, and apoptosis (275).

A possible strategy to improve the clinical benefit of CAR Tcell therapy is the co-administration of targeted anti-tumor agents selected for their ability to exert immunomodulatory properties, with the aim of overcoming tumor-induced immune dysfunctions. Based on preclinical studies showing that ibrutinib could improve the anti-tumor efficacy of CAR T cells, a phase I clinical trial was conducted showing the safety and feasibility of ibrutinib administered in combination with antiCD19 CAR T cells in relapsed and refractory CLL patients (171). In line with these results, recent preclinical data show that also the novel BTK inhibitor acalabrutinib can improve the in vitro and in vivo anti-tumor functions of CD19-directed CAR T cells (276).

Besides T cells, NK cells could represent a valid cellular carrier for CAR constructs. CAR NK cells have the advantage to be activated not only by the CAR target antigen, but also by NCRs, thus adding ADCC-mediated mechanisms to the CAR-mediated cell lysis. Due to the dysregulation of patient-derived NK cells, most studies addressing the efficacy of NK cells-based adoptive immunotherapy consisted in the transfer of ex vivo expanded allogeneic NK cells derived from healthy donors' peripheral blood, umbilical cord blood, or cell lines $(277,278)$. Allogeneic NK cells can be safely used as effector cells since they do not require a full HLA-matching and they do not induce graftversus-host disease, while harboring strong graft-versusleukemia effects $(279,280)$. Cord blood-derived anti-CD19 CAR NK cells showed good activity towards CLL cells in vitro, and preliminary evidences from a clinical trial have already demonstrated the safety and efficacy of this approach in patients with CD19-positive tumors, including CLL $(274,281)$. Thanks to these reasons, CAR NK cells can be produced in allogeneic settings and easily used as an "off-the-shelf" treatment (26).

\section{Immune Checkpoint Inhibitors}

The targeting of immune checkpoint molecules with the aim of reactivating the $\mathrm{T}$-cell immune responses against tumor cells is an appealing therapeutic strategy. In the context of solid tumors, the blockade of immune checkpoint receptors or their cognate ligands by $\mathrm{mAb}$ has brought significant benefits for patients [as reviewed in (282)]. In CLL, encouraging preclinical results have been obtained in the studies that evaluated PD-1/PD-L1 axis disruption $(283,284)$. Specifically, in vivo treatment with an 
TABLE 2 | Clinical trials evaluating the efficacy and toxicity of CAR T- and CAR NK-cell treatment in CLL patients.

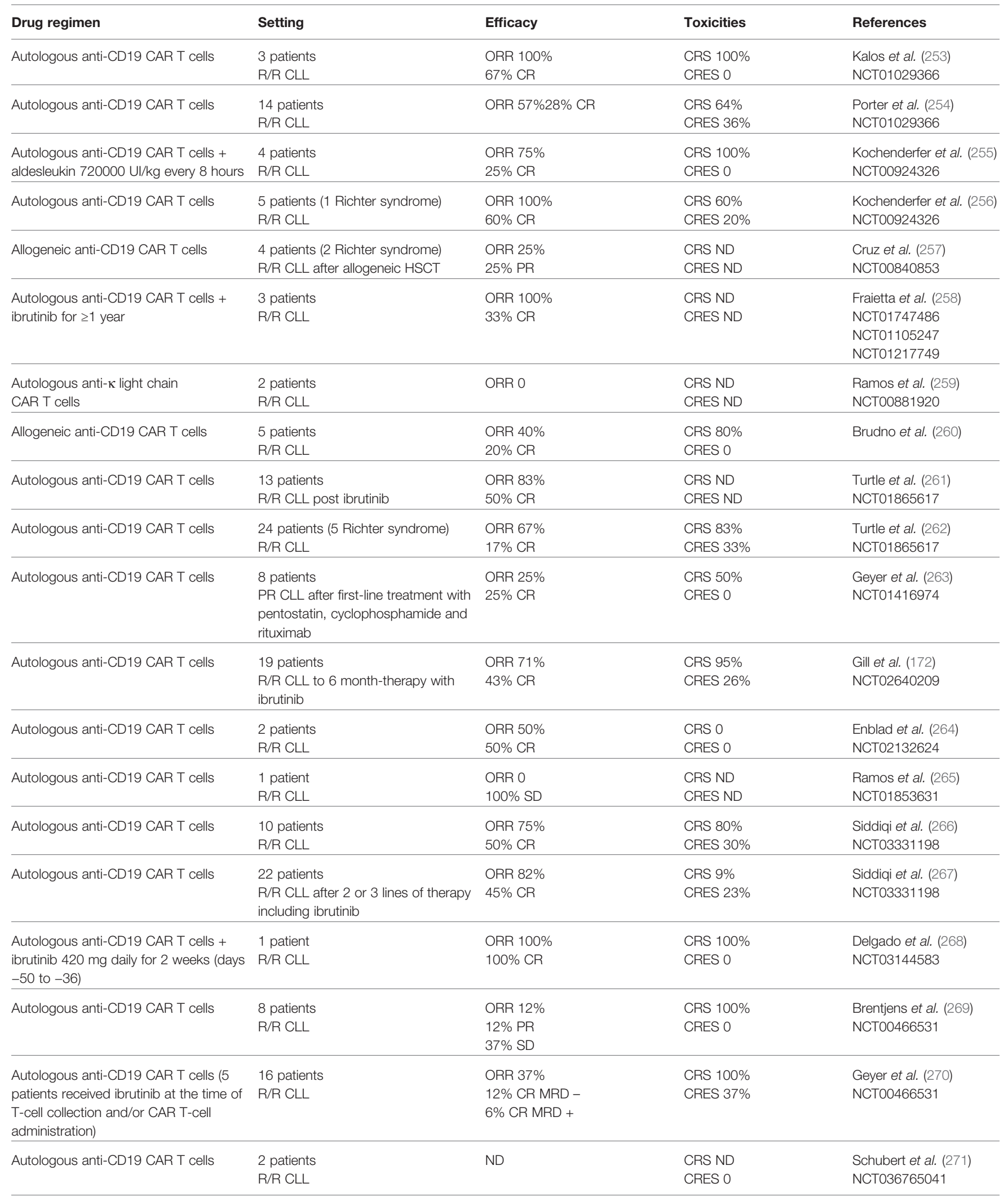


TABLE 2 | Continued

\begin{tabular}{|c|c|c|c|c|}
\hline Drug regimen & Setting & Efficacy & Toxicities & References \\
\hline Anti-CD19 CAR T cells & $\begin{array}{l}13 \text { patients (3 Richter syndrome) } \\
\text { R/R CLL }\end{array}$ & $42 \% \mathrm{CR}$ & $\begin{array}{l}\text { CRS 85\% } \\
\text { CRES 85\% }\end{array}$ & $\begin{array}{l}\text { Batlevi et al. }(272)^{1} \\
\text { NCT030851731 }\end{array}$ \\
\hline Anti-CD19/CD20 CAR T cells & $\begin{array}{l}2 \text { patients } \\
\text { R/R CLL }\end{array}$ & $\begin{array}{l}\text { ORR } 82 \% \\
54 \% \text { CR }\end{array}$ & $\begin{array}{l}\text { CRS } 54 \% \\
\text { CRES } 27 \%\end{array}$ & $\begin{array}{l}\text { Shah et al. }(273)^{1} \\
\text { NCT03019055 }\end{array}$ \\
\hline $\begin{array}{l}\text { Autologous anti-CD19 CAR T cells + } \\
\text { ibrutinib from at least } 2 \text { weeks prior to } \\
\text { leukapheresis until at least } 3 \text { months } \\
\text { after CAR T infusion vs autologous anti- } \\
\text { CD19 CAR T cells alone }\end{array}$ & $\begin{array}{l}19 \text { patients vs } 30 \text { (4 Richter } \\
\text { syndrome) }\end{array}$ & $\begin{array}{l}\text { ORR } 83 \% \\
22 \% \text { CR } \\
72 \% \text { MRD - assessed by } \\
\text { cytometry } \\
61 \% \text { MRD - assessed by IGH } \\
\text { sequencing } \\
\text { vs } \\
\text { ORR 56\% } \\
67 \% \text { MRD - assesed by } \\
\text { cytometry } \\
60 \% \text { MRD - assesed by IGH } \\
\text { sequencing }\end{array}$ & $\begin{array}{l}\text { CRS } 74 \% \text { vs } 95 \% \\
\text { CRES } 26 \% \text { vs } 42 \%\end{array}$ & $\begin{array}{l}\text { Gauthier et al. (150) } \\
\text { NCT01865617 }\end{array}$ \\
\hline $\begin{array}{l}\text { Umbilical cord blood derived anti-CD19 } \\
\text { CAR NK }\end{array}$ & $\begin{array}{l}5 \text { patients ( } 1 \text { Richter) } \\
\text { R/R CLL }\end{array}$ & $\begin{array}{l}3 / 5 \mathrm{ORR} \\
3 \mathrm{CR}\end{array}$ & $\begin{array}{l}\text { CRS } 0 \\
\text { CRES } 0\end{array}$ & $\begin{array}{l}\text { Liu et al. (274) } \\
\text { NCT03056339 }\end{array}$ \\
\hline
\end{tabular}

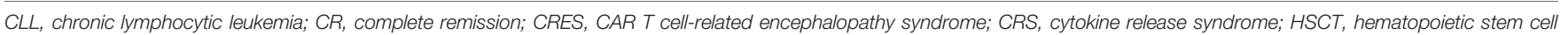
transplantation; MRD, minimal residual disease; ND, no data; ORR, overall response rate; $P R$, partial response; $R / R$ relapsed or refractory disease; $S D$, stable disease.

${ }^{1}$ Data for CLL patients only non-available.

TABLE 3 | Ongoing clinical trials evaluating CAR T-cell treatment in CLL patients.

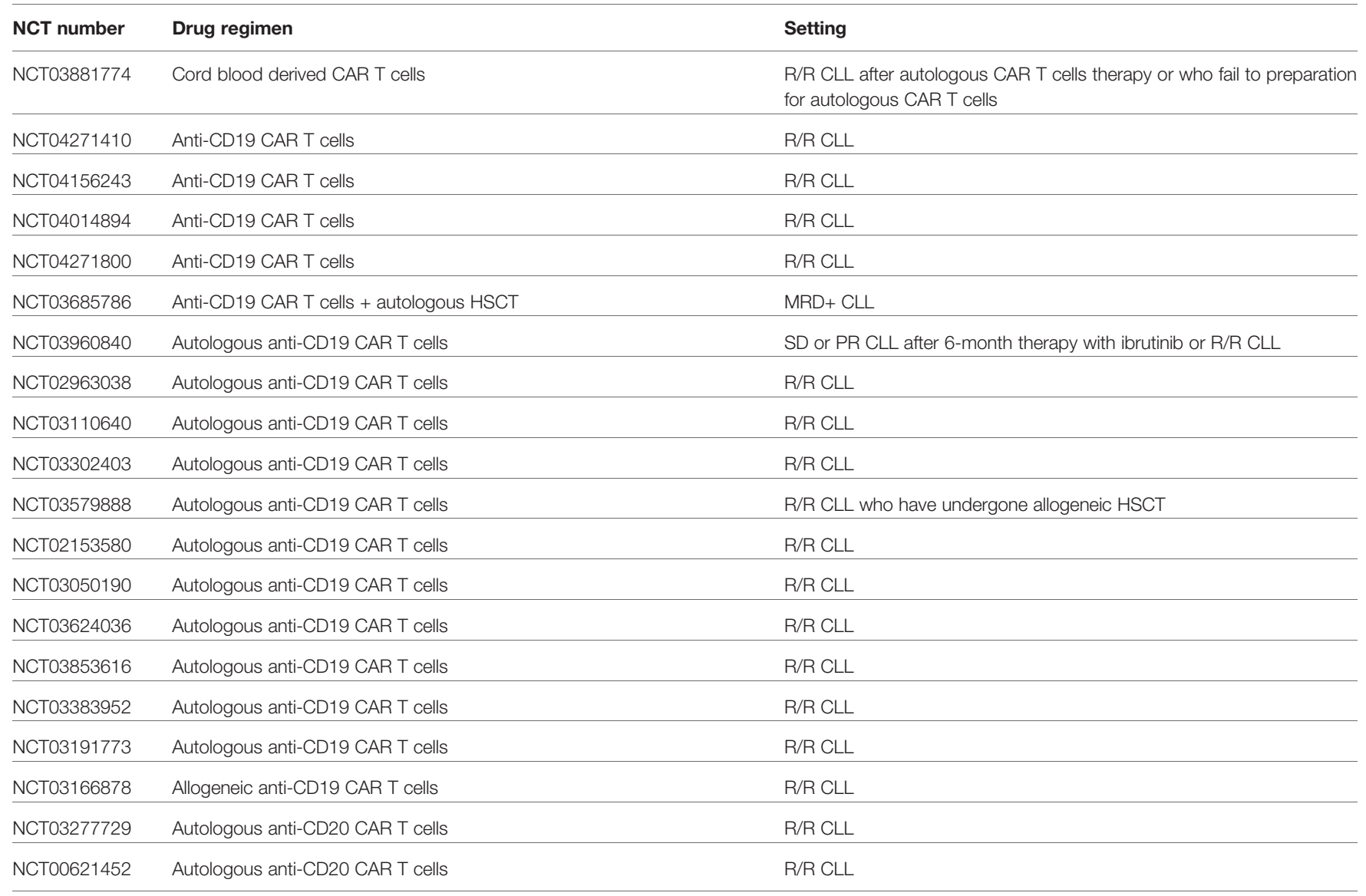


TABLE 3 | Continued

\begin{tabular}{lll}
\hline NCT number & Drug regimen & Setting \\
\hline NCT00012207 & Autologous anti-CD20 CAR T cells & R/R CLL \\
NCT01735604 & Autologous anti-CD20 CAR T cells & R/R CLL \\
\hline NCT04030195 & Allogeneic anti-CD20 CAR T cells & R/R CLL \\
\hline NCT02794961 & Autologous anti-CD22 CAR T cells & R/R CLL \\
\hline NCT02194374 & Autologous anti-ROR1 CAR T cells & R/R or untreated CLL with del17p and not eligible for allogeneic HSCT \\
\hline NCT02706392 & Autologous anti-ROR1 CAR T cells & R/R CLL \\
\hline NCT04156178 & Anti-CD19/CD20 CAR T cells & R/R CLL \\
\hline NCT04260945 & Anti-CD19/CD20 CAR T cells & R/R CLL \\
\hline NCT04007029 & Autologous anti-CD19/CD20 CAR T cells & R/R CLL \\
\hline NCT03097770 & Autologous or allogenic anti-CD19/CD20 CAR T cells & R/R CLL \\
\hline NCT03398967 & Allogeneic anti-CD19/CD20 or anti-CD19/CD22 CAR T cells & R/R CLL \\
\hline NCT04029038 & Autologous anti-CD19/CD22 CAR T cells & R/R CLL \\
\hline NCT03185494 & Autologous or allogenic anti-CD19/CD22 CAR T cells & R/R CLL \\
\hline NCT03125577 & Autologous anti-CD19 and anti-CD20/CD22/CD30/CD38/CD70/CD123 & R/R CLL \\
\hline CAR T cells & \\
\hline
\end{tabular}

CLL, chronic lymphocytic leukemia; HSCT, hematopoietic stem cell transplantation, MRD, minimal residual disease; PR partial response; R/R relapsed or refractory; SD, stable disease.

anti-PD-L1 antibody prevented the development of CLL in the $\mathrm{E} \mu$-TCL1 mice model, also normalizing T cells and myeloid cell populations, and restoring T-cell functions (283). In the same murine model, it has been demonstrated that antibodies targeting PD-L1, but not PD-1, enhance the anti-tumor activity of ibrutinib treatment $(170,284)$. Notably, Wierz et al. have shown, in the E $\mu$-TCL1 mice model, that the antibodybased dual targeting of PD-1 and LAG3-but not the single targeting of PD-1-effectively limits the tumor development and restores different immune cell populations (284). These data support the concept that the simultaneous inhibition of different immune checkpoint molecules may represent an interesting therapeutic approach, which is worth to be explored.

Unfortunately, so far, disappointing results emerged from clinical trials evaluating immune checkpoint inhibitors in CLL, indicating that these compounds used as single agents are not sufficient to control the disease (Table 4). By contrast, interesting preliminary results in terms of response rate have been obtained when checkpoint inhibitors were administered, alone or in association with ibrutinib, to CLL patients developing a Richter's transformation to diffuse large B-cell lymphoma, and particularly to those patients showing a higher expression of PDL1 and PD-1 in the tumor microenvironment $(285,289)$. These data encourage further studies exploring the efficacy of checkpoint inhibitors in this setting, which still represents a significant unmet clinical need.

\section{CONCLUSIONS}

It is well recognized that, in addition to the direct targeting of malignant cells, the disruption of the immune-tolerant microenvironment and the repair of immune system's defects are necessary steps for disease control. With the aim of harnessing immune responses against tumor cells, during the years, different types of immune-based strategies have been developed and evaluated in CLL. Despite promising preclinical observations, results from pilot clinical studies have been often suboptimal in terms of long-term tumor control, mainly because they were obtained in patients with advanced-stage disease and who had been already heavily pre-treated. In CLL, several observations demonstrate that the tumor negatively affects the host immune system, which progressively accumulates dysfunctions contributing to disease progression. Therefore, in disease like CLL, characterized by a long-acting evolution and the accumulation of immunologic dysfunction, one possibility to improve the efficacy of immunotherapy could be its earlier positioning in the treatment sequencing. By doing this, the development of immune defects could be prevented and subsequent therapies could act in concert with the patient's immune system against the tumor. However, the application of immunotherapy earlier in the course of the disease has to take into account the potential toxicities and the meaningful costs, and should be considered a valuable option only for patients with a high-risk disease and poor prognosis, who benefit less from currently available therapies.

An alternative strategy to improve patients' outcome is the identification of optimal combination treatments targeting both the CLL and the immune system, in order to reshape the functionality of the latter and properly address its reaction toward the tumor. Ibrutinib, and to some extent also next-generation BTK inhibitors and venetoclax, have shown to improve the host T-cell functions. Therefore, these targeted drugs, as well as other agents with more broad 
TABLE 4 | Clinical trials evaluating the efficacy and toxicity of immune checkpoint inhibitors, used as single agents or in combination regimens, for the treatment of patients with CLL.

\begin{tabular}{|c|c|c|c|c|}
\hline Drug regimen & Setting & Efficacy & Toxicities & References \\
\hline $\begin{array}{l}\text { Pembrolizumab every } 3 \text { weeks for } \\
\text { up to } 2 \text { years }\end{array}$ & $\begin{array}{l}\text { Phase II: } \\
25 \text { patients ( } 9 \text { Richter } \\
\text { syndrome) } \\
\text { R/R CLL }\end{array}$ & $\begin{array}{l}\text { ORR } 16 \% \\
1 \% \text { CR } \\
\text { Median PFS } 3 \text { months } \\
\text { Median OS } 10.7 \text { months }\end{array}$ & $\begin{array}{l}G \geq 3 \text { neutropenia } 20 \% \\
G \geq 3 \text { thrombocytopenia } 20 \% \\
G \geq 3 \text { anemia } 20 \% \\
G \geq 3 \text { dyspnea } 8 \% \\
G \geq 3 \text { hypoxia } 8 \% \\
G \geq 3 \text { fatigue } 8 \% \\
G \geq 3 \text { febrile neutropenia } 8 \% \\
G \geq 3 \text { fever } 4 \% \\
G \geq 3 \text { maculopapular rash } 4 \% \\
G 3 \text { lung infection } 12 \% \\
G 3 \text { hepatic toxicity } 8 \% \\
G 5 \text { sepsis } 4 \%\end{array}$ & $\begin{array}{l}\text { Ding et al. (285) } \\
\text { NCT02332980 }\end{array}$ \\
\hline $\begin{array}{l}\text { Nivolumab } 3 \text { mg/kg IV every } 2 \\
\text { weeks and ibrutinib } 420 \text { mg/day }\end{array}$ & $\begin{array}{l}\text { Phase II } \\
8 \text { patients (4 Richter } \\
\text { sydrome) } \\
\text { R/R CLL vs } 3 \text { patients } \\
\text { PR CLL to 9-month } \\
\text { ibrutinib therapy }\end{array}$ & $\begin{array}{l}\text { ORR } 75 \% \\
50 \% \text { PR } \\
\text { vs } \\
\text { ORR } 100 \% \\
100 \% \text { PR }\end{array}$ & No $G \geq 3$ AEs & $\begin{array}{l}\text { Jain et al. (286) } \\
\text { NCT02420912 }\end{array}$ \\
\hline Pidilizumab & $\begin{array}{l}\text { Phase I } \\
3 \text { patients } \\
\text { R/R CLL }\end{array}$ & $\begin{array}{l}\text { ORR } 0 \\
67 \% \text { SD }\end{array}$ & No $G \geq 3$ AEs & Berger et al. (287) \\
\hline $\begin{array}{l}\text { Samalizumab once every } 28 \text { days } \\
\text { until progression or toxicity }\end{array}$ & $\begin{array}{l}\text { Phase I } \\
23 \text { patients } \\
\text { R/R CLL }\end{array}$ & $\begin{array}{l}\text { ORR } 4 \% \\
4 \mathrm{PR}\end{array}$ & $\begin{array}{l}G \geq 3 \text { hematological AEs } 12 \% \\
G \geq 3 \text { reduced visual acuity } 4 \% \\
G \geq 3 \text { muscular weakness } 4 \% \\
G \geq 3 \text { RSV infection } 4 \% \\
G \geq 3 \text { rash } 4 \%\end{array}$ & $\begin{array}{l}\text { Mahadevan et al. (288) } \\
\text { NCT00648739 }\end{array}$ \\
\hline $\begin{array}{l}\text { Ibrutinib ( } 420 \mathrm{mg} \text { or } 560 \mathrm{mg} \text { ) and } \\
\text { nivolumab }\end{array}$ & $\begin{array}{l}\text { Phase I-lla } \\
56 \text { patients (20 Richter } \\
\text { syndrome) }\end{array}$ & ORR $97 \%$ & $\begin{array}{l}G \geq 3 \text { neutropenia } 28 \% \\
G \geq 3 \text { anemia } 23 \% \\
G \geq 3 \text { rash } 8 \% \\
G \geq 3 \text { increased } A L T 2 \% \\
\text { Serious AEs: anemia } 4 \% \text { and } \\
\text { pneumonia } 4 \%\end{array}$ & $\begin{array}{l}\text { Younes et al. (289) } \\
\text { NCT02329847 }\end{array}$ \\
\hline $\begin{array}{l}\text { For CLL: induction with umbralisib } \\
\text { and ublituximab, consolidation with } \\
\text { pembrolizumab, umbralisib and } \\
\text { ublituximab, maintenance with } \\
\text { umbralisib until progression or } \\
\text { unacceptable AE. } \\
\text { For Richter syndrome: umbralisib, } \\
\text { ublituximab and pembrolizumab }\end{array}$ & $\begin{array}{l}\text { Phase I/II } \\
14 \text { patients (5 Richter } \\
\text { syndrome) } \\
\text { R/R CLL }\end{array}$ & $\begin{array}{l}\text { CLL: ORR 89\% } \\
\text { Richter syndrome: ORR 50\%, } \\
\text { 50\% CR PFS 71\% (median } \\
\text { follow-up } 15 \text { months) }\end{array}$ & $\begin{array}{l}\mathrm{G} \geq 3 \text { neutropenia } 43 \% \\
\mathrm{G} \geq 3 \text { ALT/AST increase } 21 \% \\
\mathrm{G} \geq 3 \text { hypophosphatemia } 21 \% \\
\mathrm{G} \geq 3 \text { pneumonitis } 7 \%\end{array}$ & Mato et al. (290) \\
\hline $\begin{array}{l}\text { Nivolumab vs pembrolizumab } \\
\text { and ibrutinib in } 3 \text { patients and } \\
\text { venetoclax in } 1 \text { patient }\end{array}$ & $\begin{array}{l}7 \text { vs } 3 \text { patients } \\
\text { R/R CLL (Richter } \\
\text { syndrome) }\end{array}$ & ORR $10 \%$ & ND & Rogers et al. (291) \\
\hline Ipilimumab and lenalidomide & $\begin{array}{l}\text { Phase II } \\
2 \text { patients } \\
\text { R/R CLL to allogeneic } \\
\text { HSCT }\end{array}$ & ORR 0 & $\begin{array}{l}\text { G } \geq 3 \text { neutropenia } 40 \% \\
\text { G2 anemia } 40 \% \\
\text { G2 thrombocytopenia } 20 \% \\
\text { Flare of GVHD } 10 \% \\
\text { G2 nausea } 10 \% \\
\text { G2 headache } 10 \% \\
\text { G2 diarrhea } 10 \% \% \\
\text { G2 elevated transaminase 10\% } \\
\text { G2 hypertension } 10 \% \\
\text { G2 hypothyroidism } 10 \%\end{array}$ & $\begin{array}{l}\text { Khouri et al. (292) } \\
\text { NCT01919619 }\end{array}$ \\
\hline $\begin{array}{l}\text { Nivolumab single agent until } \\
\text { progression or unacceptable } \\
\text { toxicity, with planned deescalation } \\
\text { based on toxicity }\end{array}$ & $\begin{array}{l}\text { Phase I } \\
1 \text { patient } \\
\text { R/R CLL to allogeneic } \\
\text { HSCT }\end{array}$ & $\begin{array}{l}\text { ORR 32\% } \\
\text { 1-year PFS 23\%, 1-year OS 56\% }\end{array}$ & $\begin{array}{l}G \geq 3 \text { thrombocytopenia } 14 \% \\
G \geq 3 \text { neutropenia } 14 \% \\
G \geq 3 \text { anemia } 11 \% \\
G \geq 3 \text { febrile neutropenia } 11 \% \\
G \geq 3 \text { fatigue } 7.1 \%\end{array}$ & $\begin{array}{l}\text { Davids et al. }(293)^{1} \\
\text { NCT01822509 }\end{array}$ \\
\hline
\end{tabular}


TABLE 4 | Continued

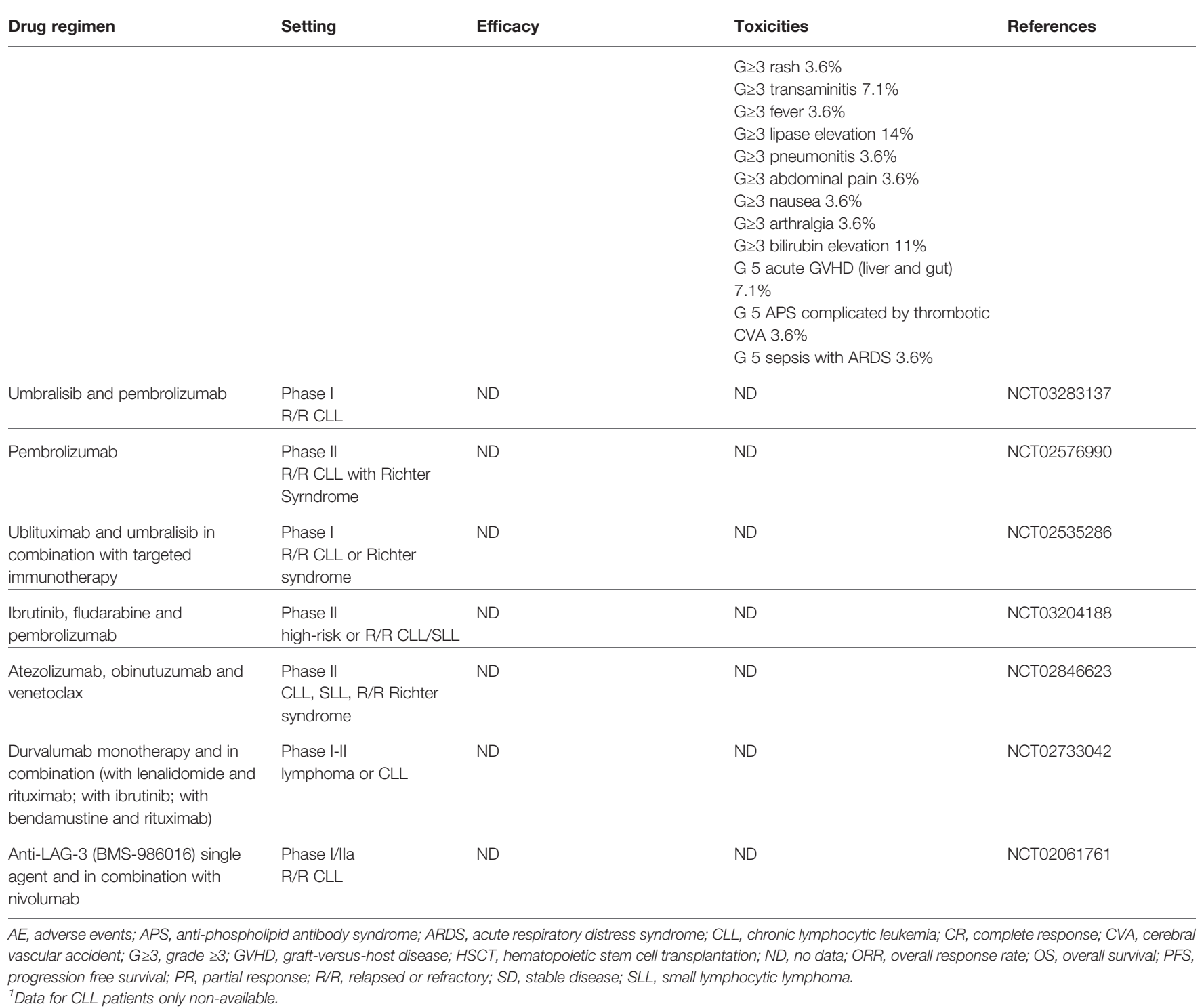

immunomodulatory properties_-such as IMiDs and checkpoint inhibitors-are currently under evaluation for their ability to potentiate the efficacy of other immunotherapeutic strategies. In this context, combination trials of ibrutinib and T-cell directed immunotherapies, such as anti-CD19 CAR T cells, have already provided promising results and support the potential of this approach.

\section{AUTHOR CONTRIBUTIONS}

VG and FP reviewed the literature and wrote the manuscript. VG and FP equally contributed to this work. CS and EB contributed to literature review. $\mathrm{MB}$ contributed to manuscript revision. $\mathrm{CV}$ and $\mathrm{MC}$ designed the review and revised the manuscript. $\mathrm{CV}$ and
MC equally contributed to this work. All authors contributed to the article and approved the submitted version.

\section{FUNDING}

This research received no external funding. VG is a recipient of a fellowship from the "Associazione Damiano per l'Ematologia".

\section{ACKNOWLEDGMENTS}

The authors would like to thank for the support Fondazione EMN Italy Onlus, Torino, Italy. MC would like to express her gratitude for the support given by Fondazione Cassa di Risparmio di Torino (CRT) while contributing to this collection of articles. 


\section{REFERENCES}

1. Hallek M. Chronic lymphocytic leukemia: 2020 update on diagnosis, risk stratification and treatment. Am J Hematol (2019) 94(11):1266-87. doi: 10.1002/ajh.25595

2. Bosch F, Dalla-Favera R. Chronic lymphocytic leukaemia: from genetics to treatment. Nat Rev Clin Oncol (2019) 16(11):684-701. doi: 10.1038/s41571019-0239-8

3. Purroy N, Wu CJ. Coevolution of Leukemia and Host Immune Cells in Chronic Lymphocytic Leukemia. Cold Spring Harbor Perspect Med (2017) 7 (4):1-19. doi: 10.1101/cshperspect.a026740

4. van Attekum MH, Eldering E, Kater AP. Chronic lymphocytic leukemia cells are active participants in microenvironmental cross-talk. Haematologica (2017) 102(9):1469-76. doi: 10.3324/haematol.2016.142679

5. Forconi F, Moss P. Perturbation of the normal immune system in patients with CLL. Blood (2015) 126(5):573-81. doi: 10.1182/blood-2015-03-567388

6. Lanasa MC, Allgood SD, Bond KM, Gockerman JP, Levesque MC, Weinberg JB. Oligoclonal TRBV gene usage among CD8(+) $\mathrm{T}$ cells in monoclonal B lymphocytosis and CLL. Br J Haematol (2009) 145(4):535-7. doi: 10.1111/j.1365-2141.2009.07635.x

7. Criado I, Rodríguez-Caballero A, Gutiérrez ML, Pedreira CE, Alcoceba M, Nieto W, et al. Low-count monoclonal B-cell lymphocytosis persists after seven years of follow up and is associated with a poorer outcome. Haematologica (2018) 103(7):1198-208. doi: 10.3324/haematol.2017.183954

8. Lanasa MC, Weinberg JB. Immunologic aspects of monoclonal B-cell lymphocytosis. Immunol Res (2011) 49(1-3):269-80. doi: 10.1007/s12026010-8188-4

9. Maitre E, Troussard X. Monoclonal B-cell lymphocytosis. Best Pract Res Clin Haematol (2019) 32(3):229-38. doi: 10.1016/j.beha.2019.06.002

10. Moreira J, Rabe KG, Cerhan JR, Kay NE, Wilson JW, Call TG, et al. Infectious complications among individuals with clinical monoclonal Bcell lymphocytosis (MBL): a cohort study of newly diagnosed cases compared to controls. Leukemia (2013) 27(1):136-41. doi: 10.1038/ leu.2012.187

11. Solomon BM, Chaffee KG, Moreira J, Schwager SM, Cerhan JR, Call TG, et al. Risk of non-hematologic cancer in individuals with high-count monoclonal B-cell lymphocytosis. Leukemia (2016) 30(2):331-6. doi: 10.1038/leu.2015.235

12. Dasanu CA, Alexandrescu DT. Risk for second nonlymphoid neoplasms in chronic lymphocytic leukemia. Med Gen Med Medscape Gen Med (2007) 9 (4):35.

13. Morrison VA. Infectious complications of chronic lymphocytic leukaemia: pathogenesis, spectrum of infection, preventive approaches. Best Pract Res Clin Haematol (2010) 23(1):145-53. doi: 10.1016/j.beha.2009.12.004

14. Falchi L, Vitale C, Keating MJ, Lerner S, Wang X, Elhor Gbito KY, et al. Incidence and prognostic impact of other cancers in a population of longterm survivors of chronic lymphocytic leukemia. Ann Oncol (2016) 27 (6):1100-6. doi: 10.1093/annonc/mdw072

15. Hilal T, Gea-Banacloche JC, Leis JF. Chronic lymphocytic leukemia and infection risk in the era of targeted therapies: Linking mechanisms with infections. Blood Rev (2018) 32(5):387-99. doi: 10.1016/j.blre.2018.03.004

16. Hamblin TJ. Autoimmune complications of chronic lymphocytic leukemia. Semin Oncol (2006) 33(2):230-9. doi: 10.1053/j.seminoncol.2006.01.011

17. Vitale C, Montalbano MC, Salvetti C, Boccellato E, Griggio V, Boccadoro M, et al. Autoimmune Complications in Chronic Lymphocytic Leukemia in the Era of Targeted Drugs. Cancers (2020) 12(2):1-21. doi: 10.3390/ cancers 12020282

18. Thompson PA, Tam CS, O'Brien SM, Wierda WG, Stingo F, Plunkett W, et al. Fludarabine, cyclophosphamide, and rituximab treatment achieves long-term disease-free survival in IGHV-mutated chronic lymphocytic leukemia. Blood (2016) 127(3):303-9. doi: 10.1182/blood-2015-09-667675

19. Jain N, Keating M, Thompson P, Ferrajoli A, Burger J, Borthakur G, et al. Ibrutinib and Venetoclax for First-Line Treatment of CLL. $N$ Engl J Med (2019) 380(22):2095-103. doi: 10.1056/NEJMoa1900574

20. Rogers KA, Huang Y, Ruppert AS, Abruzzo LV, Andersen BL, Awan FT, et al. Phase II Study of Combination Obinutuzumab, Ibrutinib, and Venetoclax in Treatment-Naïve and Relapsed or Refractory Chronic
Lymphocytic Leukemia. J Clin Oncol (2020) 38(31):3626-37. doi: 10.1200/ JCO.20.00491

21. Hillmen P, Rawstron AC, Brock K, Muñoz-Vicente S, Yates FJ, Bishop R, et al. Ibrutinib Plus Venetoclax in Relapsed/Refractory Chronic Lymphocytic Leukemia: The CLARITY Study. J Clin Oncol (2019) 37 (30):2722-9. doi: 10.1200/JCO.19.00894

22. Gribben JG, Riches JC. Immunotherapeutic strategies including transplantation: eradication of disease. Hematol Am Soc Hematol Educ Prog (2013) 2013:151-7. doi: 10.1182/asheducation-2013.1.151

23. Arruga F, Gyau BB, Iannello A, Vitale N, Vaisitti T, Deaglio S. Immune Response Dysfunction in Chronic Lymphocytic Leukemia: Dissecting Molecular Mechanisms and Microenvironmental Conditions. Int J Mol Sci (2020) 21(5):1-22. doi: 10.3390/ijms21051825

24. Haseeb M, Anwar MA, Choi S. Molecular Interactions Between Innate and Adaptive Immune Cells in Chronic Lymphocytic Leukemia and Their Therapeutic Implications. Front Immunol (2018) 9:2720. doi: 10.3389/ fimmu.2018.02720

25. Man S, Henley P. Chronic lymphocytic leukaemia: the role of T cells in a B cell disease. Br J Haematol (2019) 186(2):220-33. doi: 10.1111/bjh.15918

26. Roessner PM, Seiffert M. T-cells in chronic lymphocytic leukemia: Guardians or drivers of disease? Leukemia (2020) 34(8):2012-24. doi: 10.1038/s41375-020-0873-2

27. Wang WT, Zhu HY, Wu YJ, Xia Y, Wu JZ, Wu W, et al. Elevated absolute NK cell counts in peripheral blood predict good prognosis in chronic lymphocytic leukemia. J Cancer Res Clin Oncol (2018) 144(3):449-57. doi: $10.1007 / \mathrm{s} 00432-017-2568-2$

28. Hadadi L, Hafezi M, Amirzargar AA, Sharifian RA, Abediankenari S, Asgarian-Omran H. Dysregulated Expression of Tim-3 and NKp30 Receptors on NK Cells of Patients with Chronic Lymphocytic Leukemia. Oncol Res Treat (2019) 42(4):202-8. doi: 10.1159/000497208

29. Gonzalez-Rodriguez AP, Contesti J, Huergo-Zapico L, Lopez-Soto A, Fernandez-Guizan A, Acebes-Huerta A, et al. Prognostic significance of CD8 and CD4 T cells in chronic lymphocytic leukemia. Leukemia Lymphoma (2010) 51(10):1829-36. doi: 10.3109/10428194.2010.503820

30. Palmer S, Hanson CA, Zent CS, Porrata LF, Laplant B, Geyer SM, et al. Prognostic importance of $\mathrm{T}$ and NK-cells in a consecutive series of newly diagnosed patients with chronic lymphocytic leukaemia. $\mathrm{Br} J$ Haematol (2008) 141(5):607-14. doi: 10.1111/j.1365-2141.2008.07070.x

31. MacFarlane A, Jillab M, Smith MR, Alpaugh RK, Cole ME, Litwin S, et al. NK cell dysfunction in chronic lymphocytic leukemia is associated with loss of the mature cells expressing inhibitory killer cell Ig-like receptors. Oncoimmunology (2017) 6(7):e1330235. doi: 10.1080/2162402X.2017.1330235

32. Huergo-Zapico L, Acebes-Huerta A, Gonzalez-Rodriguez AP, Contesti J, Gonzalez-Garcia E, Payer AR, et al. Expansion of NK cells and reduction of NKG2D expression in chronic lymphocytic leukemia. Correlation Progress Dis PLoS One (2014) 9(10):e108326. doi: 10.1371/journal.pone.0108326

33. Costello RT, Knoblauch B, Sanchez C, Mercier D, Le Treut T, Sebahoun G. Expression of natural killer cell activating receptors in patients with chronic lymphocytic leukaemia. Immunology (2012) 135(2):151-7. doi: 10.1111/ j.1365-2567.2011.03521.x

34. Le Garff-Tavernier M, Herbi L, de Romeuf C, Nguyen-Khac F, Davi F, Grelier A, et al. Antibody-dependent cellular cytotoxicity of the optimized anti-CD20 monoclonal antibody ublituximab on chronic lymphocytic leukemia cells with the 17 p deletion. Leukemia (2014) 28(1):230-3. doi: 10.1038/leu.2013.240

35. Lowdell MW, Lamb L, Hoyle C, Velardi A, Prentice HG. Non-MHCrestricted cytotoxic cells: their roles in the control and treatment of leukaemias. Br J Haematol (2001) 114(1):11-24. doi: 10.1046/j.13652141.2001.02906.x

36. Ziegler HW, Kay NE, Zarling JM. Deficiency of natural killer cell activity in patients with chronic lymphocytic leukemia. Int J Cancer (1981) 27(3):3217. doi: 10.1002/ijc.2910270310

37. Katrinakis G, Kyriakou D, Papadaki H, Kalokyri I, Markidou F, Eliopoulos GD. Defective natural killer cell activity in B-cell chronic lymphocytic leukaemia is associated with impaired release of natural killer cytotoxic factor(s) but not of tumour necrosis factor-alpha. Acta Haematol (1996) 96 (1):16-23. doi: 10.1159/000203709 
38. Maki G, Hayes GM, Naji A, Tyler T, Carosella ED, Rouas-Freiss N, et al. NK resistance of tumor cells from multiple myeloma and chronic lymphocytic leukemia patients: implication of HLA-G. Leukemia (2008) 22(5):998-1006. doi: 10.1038/leu.2008.15

39. Jewell AP, Worman CP, Giles FJ, Goldstone AH, Lydyard PM. Resistance of chronic lymphocytic leukaemia cells to interferon-alpha generated lymphokine activated killer cells. Leukemia Lymphoma (1992) 7(5-6):47380. doi: 10.3109/10428199209049804

40. Spitz DL, Zucker-Franklin D, Nabi ZF. Unmasking of cryptic natural killer (NK) cell recognition sites on chronic lymphocytic leukemia lymphocytes. Am J Hematol (1988) 28(3):155-61. doi: 10.1002/ajh.2830280305

41. Veuillen C, Aurran-Schleinitz T, Castellano R, Rey J, Mallet F, Orlanducci F, et al. Primary B-CLL resistance to NK cell cytotoxicity can be overcome in vitro and in vivo by priming NK cells and monoclonal antibody therapy. J Clin Immunol (2012) 32(3):632-46. doi: 10.1007/s10875-011-9624-5

42. McWilliams EM, Mele JM, Cheney C, Timmerman EA, Fiazuddin F, Strattan EJ, et al. Therapeutic CD94/NKG2A blockade improves natural killer cell dysfunction in chronic lymphocytic leukemia. Oncoimmunology (2016) 5(10):e1226720. doi: 10.1080/2162402X.2016.1226720

43. Villa-Alvarez M, Lorenzo-Herrero S, Gonzalez-Rodriguez AP, Lopez-Soto A, Payer AR, Gonzalez-Garcia E, et al. Ig-like transcript 2 (ILT2) suppresses $\mathrm{T}$ cell function in chronic lymphocytic leukemia. Oncoimmunology (2017) 6 (10):e1353856. doi: 10.1080/2162402X.2017.1353856

44. Wagner B, da Silva Nardi F, Schramm S, Kraemer T, Celik AA, Durig J, et al. HLA-E allelic genotype correlates with HLA-E plasma levels and predicts early progression in chronic lymphocytic leukemia. Cancer (2017) 123 (5):814-23. doi: $10.1002 /$ cncr.30427

45. Rizzo R, Audrito V, Vacca P, Rossi D, Brusa D, Stignani M, et al. HLA-G is a component of the chronic lymphocytic leukemia escape repertoire to generate immune suppression: impact of the HLA-G 14 base pair (rs66554220) polymorphism. Haematologica (2014) 99(5):888-96. doi: 10.3324/haematol.2013.095281

46. Hofland T, Endstra S, Gomes CKP, de Boer R, de Weerdt I, Bobkov V, et al. Natural Killer Cell Hypo-responsiveness in Chronic Lymphocytic Leukemia can be Circumvented In Vitro by Adequate Activating Signaling. HemaSphere (2019) 3(6):e308. doi: 10.1097/HS9.0000000000000308

47. Parry HM, Stevens T, Oldreive C, Zadran B, McSkeane T, Rudzki Z, et al. NK cell function is markedly impaired in patients with chronic lymphocytic leukaemia but is preserved in patients with small lymphocytic lymphoma. Oncotarget (2016) 7(42):68513-26. doi: 10.18632/oncotarget.12097

48. Nuckel H, Switala M, Sellmann L, Horn PA, Durig J, Duhrsen U, et al. The prognostic significance of soluble NKG2D ligands in B-cell chronic lymphocytic leukemia. Leukemia (2010) 24(6):1152-9. doi: 10.1038/ leu.2010.74

49. Sanchez-Martinez D, Lanuza PM, Gomez N, Muntasell A, Cisneros E, Moraru M, et al. Activated Allogeneic NK Cells Preferentially Kill Poor Prognosis B-Cell Chronic Lymphocytic Leukemia Cells. Front Immunol (2016) 7:454. doi: 10.3389/fimmu.2016.00454

50. Reiners KS, Topolar D, Henke A, Simhadri VR, Kessler J, Sauer M, et al. Soluble ligands for NK cell receptors promote evasion of chronic lymphocytic leukemia cells from NK cell anti-tumor activity. Blood (2013) 121(18):3658-65. doi: 10.1182/blood-2013-01-476606

51. Laprevotte E, Voisin G, Ysebaert L, Klein C, Daugrois C, Laurent G, et al. Recombinant human IL-15 trans-presentation by B leukemic cells from chronic lymphocytic leukemia induces autologous NK cell proliferation leading to improved anti-CD20 immunotherapy. I Immunol (Baltimore Md 1950) (2013) 191(7):3634-40. doi: 10.4049/jimmunol.1300187

52. Hemati M, Rasouli Nejad Z, Shokri MR, Ghahremanfard F, Mir Mohammadkhani M, Kokhaei P. IL-27 impact on NK cells activity: Implication for a robust anti-tumor response in chronic lymphocytic leukemia. Int Immunopharmacol (2020) 82:106350. doi: 10.1016/ j.intimp.2020.106350

53. Eskelund CW, Nederby L, Thysen AH, Skovbo A, Roug AS, Hokland ME. Interleukin-21 and rituximab enhance NK cell functionality in patients with B-cell chronic lymphocytic leukaemia. Leukemia Res (2011) 35(7):914-20. doi: 10.1016/j.leukres.2011.02.006

54. Lin H, Nieda M, Rozenkov V, Nicol AJ. Analysis of the effect of different NKT cell subpopulations on the activation of CD4 and CD8 T cells, NK cells, and B cells. Exp Hematol (2006) 34(3):289-95. doi: 10.1016/ j.exphem.2005.12.008

55. Lynch L, Michelet X, Zhang S, Brennan PJ, Moseman A, Lester C, et al. Regulatory iNKT cells lack expression of the transcription factor PLZF and control the homeostasis of $\mathrm{T}(\mathrm{reg})$ cells and macrophages in adipose tissue. Nat Immunol (2015) 16(1):85-95. doi: 10.1038/ni.3047

56. O’Reilly A, Murphy J, Rawe S, Garvey M. Chronic Lymphocytic Leukemia: A Review of Front-line Treatment Options, With a Focus on Elderly CLL Patients. Clin Lymphoma Myeloma Leukemia (2018) 18(4):249-56. doi: $10.1016 / j . c l m l .2018 .02 .003$

57. Vincent MS, Leslie DS, Gumperz JE, Xiong X, Grant EP, Brenner MB. CD1dependent dendritic cell instruction. Nat Immunol (2002) 3(12):1163-8. doi: $10.1038 /$ ni851

58. Weinkove R, Brooks CR, Carter JM, Hermans IF, Ronchese F. Functional invariant natural killer T-cell and CD1d axis in chronic lymphocytic leukemia: implications for immunotherapy. Haematologica (2013) 98 (3):376-84. doi: 10.3324/haematol.2012.072835

59. Ghnewa YG, O'Reilly VP, Vandenberghe E, Browne PV, McElligott AM, Doherty DG. Retinoic acid induction of CD1d expression primes chronic lymphocytic leukemia B cells for killing by $\mathrm{CD} 8(+)$ invariant natural killer T cells. Clin Immunol (Orlando Fla) (2017) 183:91-8. doi: 10.1016/ j.clim.2017.08.002

60. Gorini F, Azzimonti L, Delfanti G, Scarfo L, Scielzo C, Bertilaccio MT, et al. Invariant NKT cells contribute to chronic lymphocytic leukemia surveillance and prognosis. Blood (2017) 129(26):3440-51. doi: 10.1182/blood-2016-11751065

61. Bojarska-Junak A, Hus I, Chocholska S, Tomczak W, Wos J, Czubak P, et al. CD1d expression is higher in chronic lymphocytic leukemia patients with unfavorable prognosis. Leukemia Res (2014) 38(4):435-42. doi: 10.1016/ j.leukres.2013.12.015

62. Zaborsky N, Gassner FJ, Asslaber D, Reinthaler P, Denk U, Flenady S, et al. CD1d expression on chronic lymphocytic leukemia B cells affects disease progression and induces $\mathrm{T}$ cell skewing in $\mathrm{CD} 8$ positive and $\mathrm{CD} 4 \mathrm{CD} 8$ double negative T cells. Oncotarget (2016) 7(31):49459-69. doi: 10.18632/ oncotarget.10372

63. Bojarska-Junak A, Waldowska M, Wos J, Chocholska S, Hus I, Tomczak W, et al. Intracellular IL-4 and IFN-gamma expression in iNKT cells from patients with chronic lymphocytic leukemia. Oncol Lett (2018) 15(2):158090. doi: 10.3892/ol.2017.7484

64. Fais F, Morabito F, Stelitano C, Callea V, Zanardi S, Scudeletti M, et al. CD1d is expressed on B-chronic lymphocytic leukemia cells and mediates alphagalactosylceramide presentation to natural killer T lymphocytes. Int J Cancer (2004) 109(3):402-11. doi: 10.1002/ijc.11723

65. Poggi A, Venturino C, Catellani S, Clavio M, Miglino M, Gobbi M, et al. Vdelta1 T lymphocytes from B-CLL patients recognize ULBP3 expressed on leukemic B cells and up-regulated by trans-retinoic acid. Cancer Res (2004) 64(24):9172-9. doi: 10.1158/0008-5472.CAN-04-2417

66. Correia DV, Fogli M, Hudspeth K, da Silva MG, Mavilio D, Silva-Santos B. Differentiation of human peripheral blood Vdelta1+ T cells expressing the natural cytotoxicity receptor NKp30 for recognition of lymphoid leukemia cells. Blood (2011) 118(4):992-1001. doi: 10.1182/blood-201102-339135

67. Almeida AR, Correia DV, Fernandes-Platzgummer A, da Silva CL, da Silva MG, Anjos DR, et al. Delta One T Cells for Immunotherapy of Chronic Lymphocytic Leukemia: Clinical-Grade Expansion/Differentiation and Preclinical Proof of Concept. Clin Cancer Res (2016) 22(23):5795-804. doi: 10.1158/1078-0432.CCR-16-0597

68. Castella B, Vitale C, Coscia M, Massaia M. V $\gamma 9 \mathrm{~V} \delta 2$ T cell-based immunotherapy in hematological malignancies: from bench to bedside. Cell Mol Life Sci CMLS (2011) 68(14):2419-32. doi: 10.1007/s00018-0110704-8

69. Coscia M, Vitale C, Peola S, Foglietta M, Rigoni M, Griggio V, et al. Dysfunctional Vgamma9Vdelta2 $\mathrm{T}$ cells are negative prognosticators and markers of dysregulated mevalonate pathway activity in chronic lymphocytic leukemia cells. Blood (2012) 120(16):3271-9. doi: 10.1182/ blood-2012-03-417519

70. de Weerdt I, Hofland T, Lameris R, Endstra S, Jongejan A, Moerland PD, et al. Improving CLL Vgamma9Vdelta2-T-cell fitness for cellular therapy by 
ex vivo activation and ibrutinib. Blood (2018) 132(21):2260-72. doi: 10.1182/ blood-2017-12-822569

71. Orsini E, Guarini A, Chiaretti S, Mauro FR, Foa R. The circulating dendritic cell compartment in patients with chronic lymphocytic leukemia is severely defective and unable to stimulate an effective T-cell response. Cancer Res (2003) 63(15):4497-506

72. Toniolo PA, Liu S, Yeh JE, Ye DQ, Barbuto JA, Frank DA. Deregulation of SOCS5 suppresses dendritic cell function in chronic lymphocytic leukemia. Oncotarget (2016) 7(29):46301-14. doi: 10.18632/oncotarget.10093

73. Junevik K, Werlenius O, Fogelstrand L, Karlsson-Parra A, Andersson PO. High functional CD70 expression on $\alpha$-type 1-polarized dendritic cells from patients with chronic lymphocytic leukaemia. Scand J Immunol (2014) 79 (6):415-22. doi: 10.1111/sji.12172

74. Palma M, Hansson L, Choudhury A, Nasman-Glaser B, Eriksson I, Adamson L, et al. Vaccination with dendritic cells loaded with tumor apoptotic bodies (Apo-DC) in patients with chronic lymphocytic leukemia: effects of various adjuvants and definition of immune response criteria. Cancer Immunol Immunother CII (2012) 61(6):865-79. doi: 10.1007/s00262-011-1149-5

75. Palma M, Hansson L, Mulder TA, Adamson L, Nasman-Glaser B, Eriksson I, et al. Lenalidomide as immune adjuvant to a dendritic cell vaccine in chronic lymphocytic leukemia patients. Eur J Haematol (2018) 101(1):68-77. doi: 10.1111/ejh.13065

76. Gustafsson K, Junevik K, Werlenius O, Holmgren S, Karlsson-Parra A, Andersson PO. Tumour-loaded $\alpha$-type 1-polarized dendritic cells from patients with chronic lymphocytic leukaemia produce a superior NK-, NKT- and CD8+ T cell-attracting chemokine profile. Scand J Immunol (2011) 74(3):318-26. doi: 10.1111/j.1365-3083.2011.02580.x

77. Adamson L, Palma M, Choudhury A, Eriksson I, Näsman-Glaser B, Hansson $\mathrm{M}$, et al. Generation of a dendritic cell-based vaccine in chronic lymphocytic leukaemia using CliniMACS platform for large-scale production. Scand J Immunol (2009) 69(6):529-36. doi: 10.1111/j.13653083.2009.02249.x

78. Matutes E, Wechsler A, Gomez R, Cherchi M, Catovsky D. Unusual T-cell phenotype in advanced B-chronic lymphocytic leukaemia. Br J Haematol (1981) 49(4):635-42. doi: 10.1111/j.1365-2141.1981.tb07274.x

79. Platsoucas CD, Galinski M, Kempin S, Reich L, Clarkson B, Good RA. Abnormal $\mathrm{T}$ lymphocyte subpopulations in patients with $\mathrm{B}$ cell chronic lymphocytic leukemia: an analysis by monoclonal antibodies. J Immunol (Baltimore Md 1950) (1982) 129(5):2305-12.

80. Herrmann F, Lochner A, Philippen H, Jauer B, Ruhl H. Imbalance of T cell subpopulations in patients with chronic lymphocytic leukaemia of the B cell type. Clin Exp Immunol (1982) 49(1):157-62.

81. Catovsky D, Miliani E, Okos A, Galton DA. Clinical significance of T-cells in chronic lymphocytic leukaemia. Lancet (London England) (1974) 2 (7883):751-2. doi: 10.1016/S0140-6736(74)90944-1

82. Nunes C, Wong R, Mason M, Fegan C, Man S, Pepper C. Expansion of a CD8(+)PD-1(+) replicative senescence phenotype in early stage CLL patients is associated with inverted $\mathrm{CD} 4: \mathrm{CD} 8$ ratios and disease progression. Clin Cancer Res (2012) 18(3):678-87. doi: 10.1158/10780432.CCR-11-2630

83. Wu J, Xu X, Lee EJ, Shull AY, Pei L, Awan F, et al. Phenotypic alteration of $\mathrm{CD} 8+\mathrm{T}$ cells in chronic lymphocytic leukemia is associated with epigenetic reprogramming. Oncotarget (2016) 7(26):40558-70. doi: 10.18632/ oncotarget.9941

84. Guarini A, Gaidano G, Mauro FR, Capello D, Mancini F, De Propris MS, et al. Chronic lymphocytic leukemia patients with highly stable and indolent disease show distinctive phenotypic and genotypic features. Blood (2003) 102 (3):1035-41. doi: 10.1182/blood-2002-12-3639

85. Palma M, Gentilcore G, Heimersson K, Mozaffari F, Nasman-Glaser B, Young E, et al. T cells in chronic lymphocytic leukemia display dysregulated expression of immune checkpoints and activation markers. Haematologica (2017) 102(3):562-72. doi: 10.3324/haematol.2016.151100

86. Podhorecka M, Dmoszynska A, Rolinski J, Wasik E. T type 1/type 2 subsets balance in B-cell chronic lymphocytic leukemia-the three-color flow cytometry analysis. Leukemia Res (2002) 26(7):657-60. doi: 10.1016/ S0145-2126(01)00194-1
87. Roessner PM, Hanna BS, Öztürk S, Schulz R, Llaó Cid L, Yazdanparast H, et al. TBET-expressing Th1 CD4(+) $\mathrm{T}$ cells accumulate in chronic lymphocytic leukaemia without affecting disease progression in E $\mu$-TCL1 mice. Br J Haematol (2020) 189(1):133-45. doi: 10.1111/bjh.16316

88. Manna A, Kellett T, Aulakh S, Lewis-Tuffin LJ, Dutta N, Knutson K, et al. Targeting CD38 is lethal to Breg-like chronic lymphocytic leukemia cells and Tregs, but restores CD8+ T-cell responses. Blood Adv (2020) 4(10):2143-57. doi: 10.1182/bloodadvances.2019001091

89. Brusa D, Serra S, Coscia M, Rossi D, D’Arena G, Laurenti L, et al. The PD-1/ PD-L1 axis contributes to T-cell dysfunction in chronic lymphocytic leukemia. Haematologica (2013) 98(6):953-63. doi: 10.3324/ haematol.2012.077537

90. Hanna BS, Roessner PM, Yazdanparast H, Colomer D, Campo E, Kugler S, et al. Control of chronic lymphocytic leukemia development by clonallyexpanded CD8(+) T-cells that undergo functional exhaustion in secondary lymphoid tissues. Leukemia (2019) 33(3):625-37. doi: 10.1038/s41375-0180250-6

91. Serrano D, Monteiro J, Allen SL, Kolitz J, Schulman P, Lichtman SM, et al. Clonal expansion within the $\mathrm{CD} 4+\mathrm{CD} 57+$ and $\mathrm{CD} 8+\mathrm{CD} 57+\mathrm{T}$ cell subsets in chronic lymphocytic leukemia. J Immunol (Baltimore Md 1950) (1997) 158(3):1482-9.

92. Van den Hove LE, Vandenberghe P, Van Gool SW, Ceuppens JL, Demuynck H, Verhoef GE, et al. Peripheral blood lymphocyte subset shifts in patients with untreated hematological tumors: evidence for systemic activation of the $\mathrm{T}$ cell compartment. Leukemia Res (1998) 22(2):175-84. doi: 10.1016/S0145-2126(97) 00152-5

93. Riches JC, Davies JK, McClanahan F, Fatah R, Iqbal S, Agrawal S, et al. T cells from CLL patients exhibit features of T-cell exhaustion but retain capacity for cytokine production. Blood (2013) 121(9):1612-21. doi: 10.1182/blood-2012-09-457531

94. Tonino SH, van de Berg PJ, Yong SL, ten Berge IJ, Kersten MJ, van Lier RA, et al. Expansion of effector T cells associated with decreased PD-1 expression in patients with indolent B cell lymphomas and chronic lymphocytic leukemia. Leukemia Lymphoma (2012) 53(9):1785-94. doi: 10.3109/ 10428194.2012.673224

95. te Raa GD, Pascutti MF, García-Vallejo JJ, Reinen E, Remmerswaal EB, ten Berge IJ, et al. CMV-specific CD8+ T-cell function is not impaired in chronic lymphocytic leukemia. Blood (2014) 123(5):717-24. doi: 10.1182/blood2013-08-518183

96. Vardi A, Agathangelidis A, Stalika E, Karypidou M, Siorenta A, Anagnostopoulos A, et al. Antigen Selection Shapes the T-cell Repertoire in Chronic Lymphocytic Leukemia. Clin Cancer Res (2016) 22(1):167-74. doi: 10.1158/1078-0432.CCR-14-3017

97. Blanco G, Vardi A, Puiggros A, Gomez-Llonin A, Muro M, RodriguezRivera M, et al. Restricted T cell receptor repertoire in CLL-like monoclonal B cell lymphocytosis and early stage CLL. Oncoimmunology (2018) 7(6): e1432328. doi: 10.1080/2162402X.2018.1432328

98. Gorgun G, Holderried TA, Zahrieh D, Neuberg D, Gribben JG. Chronic lymphocytic leukemia cells induce changes in gene expression of CD4 and CD8 T cells. J Clin Invest (2005) 115(7):1797-805. doi: 10.1172/JCI24176

99. Ramsay AG, Clear AJ, Fatah R, Gribben JG. Multiple inhibitory ligands induce impaired T-cell immunologic synapse function in chronic lymphocytic leukemia that can be blocked with lenalidomide: establishing a reversible immune evasion mechanism in human cancer. Blood (2012) 120 (7):1412-21. doi: 10.1182/blood-2012-02-411678

100. Ramsay AG, Johnson AJ, Lee AM, Gorgun G, Le Dieu R, Blum W, et al. Chronic lymphocytic leukemia $\mathrm{T}$ cells show impaired immunological synapse formation that can be reversed with an immunomodulating drug. J Clin Invest (2008) 118(7):2427-37. doi: 10.1172/JCI35017

101. Kabanova A, Sanseviero F, Candi V, Gamberucci A, Gozzetti A, Campoccia G, et al. Human Cytotoxic T Lymphocytes Form Dysfunctional Immune Synapses with B Cells Characterized by Non-Polarized Lytic Granule Release. Cell Rep (2016) 15(1):9-18. doi: 10.1016/j.celrep.2016.02.084

102. Ramsay AG, Evans R, Kiaii S, Svensson L, Hogg N, Gribben JG. Chronic lymphocytic leukemia cells induce defective LFA-1-directed T-cell motility by altering Rho GTPase signaling that is reversible with lenalidomide. Blood (2013) 121(14):2704-14. doi: 10.1182/blood-2012-08-448332 
103. van Bruggen JAC, Martens AWJ, Fraietta JA, Hofland T, Tonino SH, Eldering E, et al. Chronic lymphocytic leukemia cells impair mitochondrial fitness in CD8(+) T cells and impede CAR T-cell efficacy. Blood (2019) 134(1):44-58. doi: 10.1182/blood.2018885863

104. Motta M, Rassenti L, Shelvin BJ, Lerner S, Kipps TJ, Keating MJ, et al. Increased expression of CD152 (CTLA-4) by normal T lymphocytes in untreated patients with B-cell chronic lymphocytic leukemia. Leukemia (2005) 19(10):1788-93. doi: 10.1038/sj.leu.2403907

105. Novak M, Prochazka V, Turcsanyi P, Papajik T. Numbers of CD8+PD-1+ and CD4+PD-1+ Cells in Peripheral Blood of Patients with Chronic Lymphocytic Leukemia Are Independent of Binet Stage and Are Significantly Higher Compared to Healthy Volunteers. Acta Haematol (2015) 134(4):208-14. doi: 10.1159/000381468

106. Rusak M, Eljaszewicz A, Bolkun L, Luksza E, Lapuc I, Piszcz J, et al. Prognostic significance of PD-1 expression on peripheral blood CD4+ T cells in patients with newly diagnosed chronic lymphocytic leukemia. Polskie Archiwum Medycyny Wewnetrznej (2015) 125(7-8):553-9. doi: 10.20452/ pamw.2967

107. Shapiro M, Herishanu Y, Katz BZ, Dezorella N, Sun C, Kay S, et al. Lymphocyte activation gene 3: a novel therapeutic target in chronic lymphocytic leukemia. Haematologica (2017) 102(5):874-82. doi: 10.3324/ haematol.2016.148965

108. Taghiloo S, Allahmoradi E, Tehrani M, Hossein-Nataj H, Shekarriz R, Janbabaei G, et al. Frequency and functional characterization of exhausted CD8(+) T cells in chronic lymphocytic leukemia. Eur J Haematol (2017) 98 (6):622-31. doi: 10.1111/ejh.12880

109. Catakovic K, Gassner FJ, Ratswohl C, Zaborsky N, Rebhandl S, Schubert M, et al. TIGIT expressing CD4+T cells represent a tumor-supportive $\mathrm{T}$ cell subset in chronic lymphocytic leukemia. Oncoimmunology (2017) 7(1): e1371399. doi: 10.1080/2162402X.2017.1371399

110. Wierz M, Janji B, Berchem G, Moussay E, Paggetti J. High-dimensional mass cytometry analysis revealed microenvironment complexity in chronic lymphocytic leukemia. Oncoimmunology (2018) 7(8):e1465167. doi: 10.1080/2162402X.2018.1465167

111. Taghiloo S, Allahmoradi E, Ebadi R, Tehrani M, Hosseini-Khah Z, Janbabaei G, et al. Upregulation of Galectin-9 and PD-L1 Immune Checkpoints Molecules in Patients with Chronic Lymphocytic Leukemia. Asian Pacific J Cancer Prev APJCP (2017) 18(8):2269-74. doi: 10.22034/ APJCP.2017.18.8.2269

112. Ciszak L, Frydecka I, Wolowiec D, Szteblich A, Kosmaczewska A. Patients with chronic lymphocytic leukaemia (CLL) differ in the pattern of CTLA-4 expression on CLL cells: the possible implications for immunotherapy with CTLA-4 blocking antibody. Tumour Biol J Int Soc Oncodevelopment Biol Med (2016) 37(3):4143-57. doi: 10.1007/s13277-015-4217-1

113. Elston L, Fegan C, Hills R, Hashimdeen SS, Walsby E, Henley P, et al. Increased frequency of CD4(+) PD-1(+) HLA-DR(+) T cells is associated with disease progression in CLL. Br J Haematol (2020) 188(6):872-80. doi: $10.1111 /$ bjh. 16260

114. de Weerdt I, Hofland T, de Boer R, Dobber JA, Dubois J, van Nieuwenhuize D, et al. Distinct immune composition in lymph node and peripheral blood of CLL patients is reshaped during venetoclax treatment. Blood Adv (2019) 3(17):2642-52. doi: 10.1182/bloodadvances. 2019000360

115. Serra S, Vaisitti T, Audrito V, Bologna C, Buonincontri R, Chen SS, et al. Adenosine signaling mediates hypoxic responses in the chronic lymphocytic leukemia microenvironment. Blood Adv (2016) 1(1):47-61. doi: 10.1182/ bloodadvances.2016000984

116. D’Arena G, Laurenti L, Minervini MM, Deaglio S, Bonello L, De Martino L, et al. Regulatory T-cell number is increased in chronic lymphocytic leukemia patients and correlates with progressive disease. Leukemia Res (2011) 35 (3):363-8. doi: 10.1016/j.leukres.2010.08.010

117. Jadidi-Niaragh F, Yousefi M, Memarian A, Hojjat-Farsangi M, Khoshnoodi J, Razavi SM, et al. Increased frequency of CD8+ and CD4+ regulatory T cells in chronic lymphocytic leukemia: association with disease progression. Cancer Invest (2013) 31(2):121-31. doi: 10.3109/07357907.2012.756110

118. Dasgupta A, Mahapatra M, Saxena R. A study for proposal of use of regulatory $\mathrm{T}$ cells as a prognostic marker and establishing an optimal threshold level for their expression in chronic lymphocytic leukemia.
Leukemia Lymphoma (2015) 56(6):1831-8. doi: 10.3109/10428194. 2014.966245

119. D’Arena G, Vitale C, Coscia M, Festa A, Di Minno NMD, De Feo V, et al. Regulatory T Cells and Their Prognostic Relevance in Hematologic Malignancies. J Immunol Res (2017) 2017:1832968. doi: 10.1155/2017/ 1832968

120. Mpakou VE, Ioannidou HD, Konsta E, Vikentiou M, Spathis A, Kontsioti F, et al. Quantitative and qualitative analysis of regulatory $\mathrm{T}$ cells in B cell chronic lymphocytic leukemia. Leukemia Res (2017) 60:74-81. doi: 10.1016/ j.leukres.2017.07.004

121. Hanna BS, Roessner PM, Scheffold A, Jebaraj BMC, Demerdash Y, Ozturk S, et al. PI3Kdelta inhibition modulates regulatory and effector T-cell differentiation and function in chronic lymphocytic leukemia. Leukemia (2019) 33(6):1427-38. doi: 10.1038/s41375-018-0318-3

122. Jak M, Mous R, Remmerswaal EB, Spijker R, Jaspers A, Yague A, et al. Enhanced formation and survival of CD4+ CD25hi Foxp3+ T-cells in chronic lymphocytic leukemia. Leukemia Lymphoma (2009) 50(5):788801. doi: 10.1080/10428190902803677

123. Beyer M, Kochanek M, Darabi K, Popov A, Jensen M, Endl E, et al. Reduced frequencies and suppressive function of $\mathrm{CD} 4+\mathrm{CD} 25$ hi regulatory $\mathrm{T}$ cells in patients with chronic lymphocytic leukemia after therapy with fludarabine. Blood (2005) 106(6):2018-25. doi: 10.1182/blood-2005-02-0642

124. Chellappa S, Kushekhar K, Munthe LA, Tjonnfjord GE, Aandahl EM, Okkenhaug K, et al. The PI3K p110delta Isoform Inhibitor Idelalisib Preferentially Inhibits Human Regulatory T Cell Function. I Immunol (Baltimore Md 1950) (2019) 202(5):1397-405. doi: 10.4049/ jimmunol.1701703

125. Lindqvist CA, Christiansson LH, Thörn I, Mangsbo S, Paul-Wetterberg G, Sundström C, et al. Both CD4+ FoxP3+ and CD4+ FoxP3- T cells from patients with B-cell malignancy express cytolytic markers and kill autologous leukaemic B cells in vitro. Immunology (2011) 133(3):296-306. doi: 10.1111/ j.1365-2567.2011.03439.x

126. De Matteis S, Molinari C, Abbati G, Rossi T, Napolitano R, Ghetti M, et al. Immunosuppressive Treg cells acquire the phenotype of effector-T cells in chronic lymphocytic leukemia patients. J Trans Med (2018) 16(1):172. doi: $10.1186 /$ s12967-018-1545-0

127. Gorczynski RM. IL-17 Signaling in the Tumor Microenvironment. Adv Exp Med Biol (2020) 1240:47-58. doi: 10.1007/978-3-030-38315-2 4

128. Lad DP, Varma S, Varma N, Sachdeva MU, Bose P, Malhotra P. Regulatory $\mathrm{T}$-cell and T-helper 17 balance in chronic lymphocytic leukemia progression and autoimmune cytopenias. Leukemia Lymphoma (2015) 56(8):2424-8. doi: 10.3109/10428194.2014.986479

129. Hus I, Bojarska-Junak A, Chocholska S, Tomczak W, Wos J, Dmoszynska A, et al. Th17/IL-17A might play a protective role in chronic lymphocytic leukemia immunity. PLoS One (2013) 8(11):e78091. doi: 10.1371/ journal.pone.0078091

130. Jadidi-Niaragh F, Ghalamfarsa G, Memarian A, Asgarian-Omran H, Razavi SM, Sarrafnejad A, et al. Downregulation of IL-17-producing T cells is associated with regulatory $\mathrm{T}$ cell expansion and disease progression in chronic lymphocytic leukemia. Tumour Biol J Int Soc Oncodevelopment Biol Med (2013) 34(2):929-40. doi: 10.1007/s13277-012-0628-4

131. Jain P, Javdan M, Feger FK, Chiu PY, Sison C, Damle RN, et al. Th17 and non-Th17 interleukin-17-expressing cells in chronic lymphocytic leukemia: delineation, distribution, and clinical relevance. Haematologica (2012) 97 (4):599-607. doi: 10.3324/haematol.2011.047316

132. Pang N, Zhang R, Li J, Zhang Z, Yuan H, Chen G, et al. Increased IL-10/IL17 ratio is aggravated along with the prognosis of patients with chronic lymphocytic leukemia. Int Immunopharmacol (2016) 40:57-64. doi: 10.1016/ j.intimp.2016.07.008

133. Sherry B, Jain P, Chiu PY, Leung L, Allen SL, Kolitz JE, et al. Identification and characterization of distinct IL-17F expression patterns and signaling pathways in chronic lymphocytic leukemia and normal B lymphocytes. Immunol Res (2015) 63(1-3):216-27. doi: 10.1007/s12026-015-8722-5

134. Zhu F, McCaw L, Spaner DE, Gorczynski RM. Targeting the IL-17/IL-6 axis can alter growth of Chronic Lymphocytic Leukemia in vivo/in vitro. Leukemia Res (2018) 66:28-38. doi: 10.1016/j.leukres.2018.01.006

135. Gabrilovich DI. Myeloid-Derived Suppressor Cells. Cancer Immunol Res (2017) 5(1):3-8. doi: 10.1158/2326-6066.CIR-16-0297 
136. Hanna BS, Öztürk S, Seiffert M. Beyond bystanders: Myeloid cells in chronic lymphocytic leukemia. Mol Immunol (2019) 110:77-87. doi: 10.1016/ j.molimm.2017.11.014

137. Gustafson MP, Abraham RS, Lin Y, Wu W, Gastineau DA, Zent CS, et al. Association of an increased frequency of CD14+HLA-DRlo/neg monocytes with decreased time to progression in chronic lymphocytic leukaemia (CLL). Br J Haematol (2012) 156(5):674-6. doi: 10.1111/j.1365-2141.2011.08902.x

138. Jitschin R, Braun M, Buttner M, Dettmer-Wilde K, Bricks J, Berger J, et al. CLL-cells induce IDOhi CD14+HLA-DRlo myeloid-derived suppressor cells that inhibit T-cell responses and promote TRegs. Blood (2014) 124(5):75060. doi: 10.1182/blood-2013-12-546416

139. Liu J, Zhou Y, Huang Q, Qiu L. CD14(+)HLA-DR(low/-) expression: A novel prognostic factor in chronic lymphocytic leukemia. Oncol Lett (2015) 9 (3):1167-72. doi: 10.3892/ol.2014.2808

140. Zahran AM, Moeen SM, Thabet AF, Rayan A, Abdel-Rahim MH, Mohamed WMY, et al. Monocytic myeloid-derived suppressor cells in chronic lymphocytic leukemia patients: a single center experience. Leukemia Lymphoma (2020) 61(7):1645-52. doi: 10.1080/10428194.2020.1728747

141. Hanna BS, McClanahan F, Yazdanparast H, Zaborsky N, Kalter V, Rossner PM, et al. Depletion of CLL-associated patrolling monocytes and macrophages controls disease development and repairs immune dysfunction in vivo. Leukemia (2016) 30(3):570-9. doi: 10.1038/leu.2015.305

142. Haderk F, Schulz R, Iskar M, Cid LL, Worst T, Willmund KV, et al. Tumorderived exosomes modulate PD-L1 expression in monocytes. Sci Immunol (2017) 2(13):1-11. doi: 10.1126/sciimmunol.aah5509

143. Bruns H, Bottcher M, Qorraj M, Fabri M, Jitschin S, Dindorf J, et al. CLLcell-mediated MDSC induction by exosomal miR-155 transfer is disrupted by vitamin D. Leukemia (2017) 31(4):985-8. doi: 10.1038/leu.2016.378

144. Borge M, Nannini PR, Morande PE, Jancic C, Bistmans A, Bezares RF, et al. CXCL12 is a costimulator for CD4+ $\mathrm{T}$ cell activation and proliferation in chronic lymphocytic leukemia patients. Cancer Immunol Immunother CII (2013) 62(1):113-24. doi: 10.1007/s00262-012-1320-7

145. Visentin A, Compagno N, Cinetto F, Imbergamo S, Zambello R, Piazza F, et al. Clinical profile associated with infections in patients with chronic lymphocytic leukemia. Protective role of immunoglobulin replacement therapy. Haematologica (2015) 100(12):e515-8. doi: 10.3324/ haematol.2015.126763

146. Reda G, Cassin R, Gentile M, Mauro FR, Giannarelli D, Fattizzo B, et al. IgA hypogammaglobulinemia predicts outcome in chronic lymphocytic leukemia. Leukemia (2019) 33(6):1519-22. doi: 10.1038/s41375-018-0344-1

147. Mauro FR, Morabito F, Vincelli ID, Petrucci L, Campanelli M, Salaroli A, et al. Clinical relevance of hypogammaglobulinemia, clinical and biologic variables on the infection risk and outcome of patients with stage A chronic lymphocytic leukemia. Leukemia Res (2017) 57:65-71. doi: 10.1016/ j.leukres.2017.02.011

148. Crassini KR, Zhang E, Balendran S, Freeman JA, Best OG, Forsyth CJ, et al. Humoral immune failure defined by immunoglobulin class and immunoglobulin G subclass deficiency is associated with shorter treatment-free and overall survival in Chronic Lymphocytic Leukaemia. $\mathrm{Br}$ J Haematol (2018) 181(1):97-101. doi: 10.1111/bjh.15146

149. Sampalo A, Navas G, Medina F, Segundo C, Cámara C, Brieva JA. Chronic lymphocytic leukemia B cells inhibit spontaneous Ig production by autologous bone marrow cells: role of CD95-CD95L interaction. Blood (2000) 96(9):3168-74. doi: 10.1182/blood.V96.9.3168.h8003168_3168_3174

150. Motta M, Chiarini M, Ghidini C, Zanotti C, Lamorgese C, Caimi L, et al. Quantification of newly produced B and T lymphocytes in untreated chronic lymphocytic leukemia patients. J Trans Med (2010) 8:111. doi: 10.1186/14795876-8-111

151. Hamblin TJ, Oscier DG, Young BJ. Autoimmunity in chronic lymphocytic leukaemia. J Clin Pathol (1986) 39(7):713-6.

152. Kipps TJ, Carson DA. Autoantibodies in chronic lymphocytic leukemia and related systemic autoimmune diseases. Blood (1993) 81(10):2475-87. doi: 10.1182/blood.V81.10.2475.bloodjournal81102475

153. Griggio V, Mandili G, Vitale C, Capello M, Macor P, Serra S, et al. Humoral immune responses toward tumor-derived antigens in previously untreated patients with chronic lymphocytic leukemia. Oncotarget (2017) 8(2):327488. doi: $10.18632 /$ oncotarget.13712
154. Middleton O, Cosimo E, Dobbin E, McCaig AM, Clarke C, Brant AM, et al. Complement deficiencies limit CD20 monoclonal antibody treatment efficacy in CLL. Leukemia (2015) 29(1):107-14. doi: 10.1038/leu.2014.146

155. Lee BN, Gao H, Cohen EN, Badoux X, Wierda WG, Estrov Z, et al. Treatment with lenalidomide modulates T-cell immunophenotype and cytokine production in patients with chronic lymphocytic leukemia. Cancer (2011) 117(17):3999-4008. doi: 10.1002/cncr.25983

156. Kipps TJ, Choi MY. Targeted Therapy in Chronic Lymphocytic Leukemia. Cancer J (Sudbury Mass) (2019) 25(6):378-85. doi: 10.1097/ PPO.0000000000000416

157. Lampson BL, Kasar SN, Matos TR, Morgan EA, Rassenti L, Davids MS, et al. Idelalisib given front-line for treatment of chronic lymphocytic leukemia causes frequent immune-mediated hepatotoxicity. Blood (2016) 128(2):195203. doi: 10.1182/blood-2016-03-707133

158. Thompson PA, Stingo F, Keating MJ, Ferrajoli A, Burger JA, Wierda WG, et al. Outcomes of patients with chronic lymphocytic leukemia treated with first-line idelalisib plus rituximab after cessation of treatment for toxicity. Cancer (2016) 122(16):2505-11. doi: 10.1002/cncr.30069

159. Coutré SE, Barrientos JC, Brown JR, de Vos S, Furman RR, Keating MJ, et al. Management of adverse events associated with idelalisib treatment: expert panel opinion. Leukemia Lymphoma (2015) 56(10):2779-86. doi: 10.3109/ 10428194.2015.1022770

160. Stock S, Übelhart R, Schubert ML, Fan F, He B, Hoffmann JM, et al. Idelalisib for optimized CD19-specific chimeric antigen receptor $\mathrm{T}$ cells in chronic lymphocytic leukemia patients. Int J Cancer (2019) 145(5):1312-24. doi: 10.1002/ijc. 32201

161. Niemann CU, Herman SE, Maric I, Gomez-Rodriguez J, Biancotto A, Chang BY, et al. Disruption of in vivo Chronic Lymphocytic Leukemia TumorMicroenvironment Interactions by Ibrutinib-Findings from an InvestigatorInitiated Phase II Study. Clin Cancer Res (2016) 22(7):1572-82. doi: 10.1158/ 1078-0432.CCR-15-1965

162. Barrientos JC, O'Brien S, Brown JR, Kay NE, Reddy NM, Coutre S, et al. Improvement in Parameters of Hematologic and Immunologic Function and Patient Well-being in the Phase III RESONATE Study of Ibrutinib Versus Ofatumumab in Patients With Previously Treated Chronic Lymphocytic Leukemia/Small Lymphocytic Lymphoma. Clin Lymphoma Myeloma Leukemia (2018) 18(12):803-13.e7. doi: 10.1016/j.clml.2018.08.007

163. Podhorecka M, Goracy A, Szymczyk A, Kowal M, Ibanez B, JankowskaLecka $\mathrm{O}$, et al. Changes in T-cell subpopulations and cytokine network during early period of ibrutinib therapy in chronic lymphocytic leukemia patients: the significant decrease in $\mathrm{T}$ regulatory cells number. Oncotarget (2017) 8(21):34661-9. doi: 10.18632/oncotarget.16148

164. Parry HM, Mirajkar N, Cutmore N, Zuo J, Long H, Kwok M, et al. LongTerm Ibrutinib Therapy Reverses CD8(+) T Cell Exhaustion in B Cell Chronic Lymphocytic Leukaemia. Front Immunol (2019) 10:2832. doi: $10.3389 /$ fimmu.2019.02832

165. Long M, Beckwith K, Do P, Mundy BL, Gordon A, Lehman AM, et al. Ibrutinib treatment improves $\mathrm{T}$ cell number and function in CLL patients. J Clin Invest (2017) 127(8):3052-64. doi: 10.1172/JCI89756

166. Yin Q, Sivina M, Robins H, Yusko E, Vignali M, O’Brien S, et al. Ibrutinib Therapy Increases $T$ Cell Repertoire Diversity in Patients with Chronic Lymphocytic Leukemia. J Immunol (Baltimore Md 1950) (2017) 198 (4):1740-7. doi: 10.4049/jimmunol.1601190

167. Palma M, Krstic A, Pena Perez L, Berglof A, Meinke S, Wang Q, et al. Ibrutinib induces rapid down-regulation of inflammatory markers and altered transcription of chronic lymphocytic leukaemia-related genes in blood and lymph nodes. Br J Haematol (2018) 183(2):212-24. doi: 10.1111/bjh.15516

168. Kondo K, Shaim H, Thompson PA, Burger JA, Keating M, Estrov Z, et al. Ibrutinib modulates the immunosuppressive CLL microenvironment through STAT3-mediated suppression of regulatory B-cell function and inhibition of the PD-1/PD-L1 pathway. Leukemia (2018) 32(4):960-70. doi: 10.1038/leu.2017.304

169. Solman IG, Blum LK, Hoh HY, Kipps TJ, Burger JA, Barrientos JC, et al. Ibrutinib restores immune cell numbers and function in first-line and relapsed/refractory chronic lymphocytic leukemia. Leukemia Res (2020) 97:106432. doi: 10.1016/j.leukres.2020.106432 
170. Hanna BS, Yazdanparast H, Demerdash Y, Roessner PM, Schulz R, Lichter P, et al. Combining ibrutinib and checkpoint blockade improves CD8+ T-cell function and control of chronic lymphocytic leukemia in Em-TCL1 mice. Haematologica (2020) haematol.2019.238154. doi: 10.3324/haematol. 2019.238154

171. Gauthier J, Hirayama AV, Purushe J, Hay KA, Lymp J, Li DH, et al. Feasibility and efficacy of CD19-targeted CAR T cells with concurrent ibrutinib for CLL after ibrutinib failure. Blood (2020) 135(19):1650-60. doi: 10.1182/blood.2019002936

172. Gill SI, Vides V, Frey NV, Metzger S, O’Brien M, Hexner E, et al. Prospective Clinical Trial of Anti-CD19 CAR T Cells in Combination with Ibrutinib for the Treatment of Chronic Lymphocytic Leukemia Shows a High Response Rate. Blood (2018) 132(Supplement 1):298-. doi: 10.1182/blood-2018-99115418

173. Dubovsky JA, Beckwith KA, Natarajan G, Woyach JA, Jaglowski S, Zhong Y, et al. Ibrutinib is an irreversible molecular inhibitor of ITK driving a Th1selective pressure in T lymphocytes. Blood (2013) 122(15):2539-49. doi: 10.1182/blood-2013-06-507947

174. Zou YX, Zhu HY, Li XT, Xia Y, Miao KR, Zhao SS, et al. The impacts of zanubrutinib on immune cells in patients with chronic lymphocytic leukemia/small lymphocytic lymphoma. Hematol Oncol (2019) 37(4):392400. doi: 10.1002/hon.2667

175. Murakami S, Suzuki S, Hanamura I, Yoshikawa K, Ueda R, Seto M, et al. Combining T-cell-based immunotherapy with venetoclax elicits synergistic cytotoxicity to B-cell lines in vitro. Hematol Oncol (2020). doi: 10.1002/ hon. 2794

176. Kohlhapp FJ, Haribhai D, Mathew R, Duggan R, Ellis PA, Wang R, et al. Venetoclax increases intra-tumoral effector T cells and anti-tumor efficacy in combination with immune checkpoint blockade. Cancer Discovery (2020) Sep 4:CD-19-0759. doi: 10.1158/2159-8290.CD-19-0759

177. Chanan-Khan A, Miller KC, Musial L, Lawrence D, Padmanabhan S, Takeshita $\mathrm{K}$, et al. Clinical efficacy of lenalidomide in patients with relapsed or refractory chronic lymphocytic leukemia: results of a phase II study. J Clin Oncol (2006) 24(34):5343-9. doi: 10.1200/JCO.2005.05.0401

178. Ferrajoli A, Lee BN, Schlette EJ, O'Brien SM, Gao H, Wen S, et al. Lenalidomide induces complete and partial remissions in patients with relapsed and refractory chronic lymphocytic leukemia. Blood (2008) 111 (11):5291-7. doi: 10.1182/blood-2007-12-130120

179. Chen CI, Bergsagel PL, Paul H, Xu W, Lau A, Dave N, et al. Single-Agent Lenalidomide in the Treatment of Previously Untreated Chronic Lymphocytic Leukemia. J Clin Oncol (2010) 29(9):1175-81. doi: 10.1200/ JCO.2010.29.8133

180. Badoux XC, Keating MJ, Wen S, Lee BN, Sivina M, Reuben J, et al. Lenalidomide as initial therapy of elderly patients with chronic lymphocytic leukemia. Blood (2011) 118(13):3489-98. doi: 10.1182/blood2011-03-339077

181. Wendtner CM, Hallek M, Fraser GAM, Michallet A-S, Hillmen P, Dürig J, et al. Safety and efficacy of different lenalidomide starting doses in patients with relapsed or refractory chronic lymphocytic leukemia: results of an international multicenter double-blinded randomized phase II trial ${ }^{*}$. Leukemia Lymphoma (2016) 57(6):1291-9. doi: 10.3109/10428194. 2015.1128540

182. Chanan-Khan A, Egyed M, Robak T, Martinelli de Oliveira FA, Echeveste MA, Dolan S, et al. Randomized phase 3 study of lenalidomide versus chlorambucil as first-line therapy for older patients with chronic lymphocytic leukemia (the ORIGIN trial). Leukemia (2017) 31(5):1240-3. doi: $10.1038 /$ leu.2017.47

183. Badoux XC, Keating MJ, Wen S, Wierda WG, O’Brien SM, Faderl S, et al. Phase II study of lenalidomide and rituximab as salvage therapy for patients with relapsed or refractory chronic lymphocytic leukemia. J Clin Oncol (2013) 31(5):584-91. doi: 10.1200/JCO.2012.42.8623

184. James DF, Werner L, Brown JR, Wierda WG, Barrientos JC, Castro JE, et al. Lenalidomide and rituximab for the initial treatment of patients with chronic lymphocytic leukemia: a multicenter clinical-translational study from the chronic lymphocytic leukemia research consortium. J Clin Oncol (2014) 32 (19):2067-73. doi: 10.1200/JCO.2013.51.5890

185. Strati P, Takahashi K, Peterson CB, Keating MJ, Thompson PA, Daver NG, et al. Efficacy and predictors of response of lenalidomide and rituximab in patients with treatment-naive and relapsed CLL. Blood Adv (2019) 3 (9):1533-9. doi: 10.1182/bloodadvances.2019031336

186. Costa LJ, Fanning SR, Stephenson JJr., Afrin LB, Kistner-Griffin E, Bentz TA, et al. Sequential ofatumumab and lenalidomide for the treatment of relapsed and refractory chronic lymphocytic leukemia and small lymphocytic lymphoma. Leukemia Lymphoma (2015) 56(3):645-9. doi: 10.3109/ 10428194.2014.935369

187. Vitale C, Falchi L, Ten Hacken E, Gao H, Shaim H, Van Roosbroeck K, et al. Ofatumumab and Lenalidomide for Patients with Relapsed or Refractory Chronic Lymphocytic Leukemia: Correlation between Responses and Immune Characteristics. Clin Cancer Res (2016) 22(10):2359-67. doi: 10.1158/1078-0432.CCR-15-2476

188. Brown JR, Abramson J, Hochberg E, Mikler E, Dalton V, Werner L, et al. A phase I study of lenalidomide in combination with fludarabine and rituximab in previously untreated CLL/SLL. Leukemia (2010) 24(11):19725. doi: 10.1038/leu.2010.199

189. Maurer C, Pflug N, Bahlo J, Kluth S, Rhein C, Cramer P, et al. Bendamustine and rituximab in combination with lenalidomide in patients with chronic lymphocytic leukemia. Eur J Haematol (2016) 97(3):253-60. doi: 10.1111/ ejh.12714

190. Mauro FR, Carella AM, Molica S, Paoloni F, Liberati AM, Zaja F, et al. Fludarabine, cyclophosphamide and lenalidomide in patients with relapsed/ refractory chronic lymphocytic leukemia. A multicenter phase I-II GIMEMA trial. Leukemia Lymphoma (2017) 58(7):1640-7. doi: 10.1080/ 10428194.2016 .1258698

191. Ujjani C, Wang H, Skarbnik A, Trivedi N, Ramzi P, Khan N, et al. A phase 1 study of lenalidomide and ibrutinib in combination with rituximab in relapsed and refractory CLL. Blood Adv (2018) 2(7):762-8. doi: 10.1182/ bloodadvances.2017015263

192. Kater AP, van Oers MHJ, van Norden Y, van der Straten L, Driessen J, Posthuma WFM, et al. Feasibility and efficacy of addition of individualizeddose lenalidomide to chlorambucil and rituximab as first-line treatment in elderly and FCR-unfit patients with advanced chronic lymphocytic leukemia. Haematologica (2019) 104(1):147-54. doi: 10.3324/haematol.2018.193854

193. Soumerai JD, Davids MS, Werner L, Fisher DC, Armand P, Amrein PC, et al. Phase 1 study of lenalidomide, bendamustine, and rituximab in previously untreated patients with chronic lymphocytic leukemia. Leukemia Lymphoma (2019) 60(12):2931-8. doi: 10.1080/10428194.2019.1608533

194. Chen CI, Paul H, Snitzler S, Kakar S, Le LW, Wei EN, et al. A phase 2 study of lenalidomide and dexamethasone in previously untreated patients with chronic lymphocytic leukemia (CLL). Leukemia Lymphoma (2019) 60 (4):980-9. doi: 10.1080/10428194.2018.1508669

195. Itchaki G, Brown JR. Lenalidomide in the treatment of chronic lymphocytic leukemia. Expert Opin Invest Drugs (2017) 26(5):633-50. doi: 10.1080/ 13543784.2017.1313230

196. Kater AP, Tonino SH, Egle A, Ramsay AG. How does lenalidomide target the chronic lymphocytic leukemia microenvironment? Blood (2014) 124 (14):2184-9. doi: 10.1182/blood-2014-05-578286

197. Blocksidge J, Glenn M, Gandhi AK, Klippel A, Pourdehnad M, Chopra R, et al. CC-122 Has Robust Anti-Proliferative Activity in a Primary Chronic Lymphocytic Leukemia (CLL) Co-Culture Model and Is Superior to Lenalidomide. Blood (2014) 124(21):4682-. doi: 10.1182/blood.V124.21. 4682.4682

198. Ioannou N, Hagner PR, Towfic F, Gandhi AK, Stamatopoulos K, Patten PEM, et al. Eliciting Anti-Tumor T Cell Immunity in Chronic Lymphocytic Leukemia (CLL) with PD-L1/PD-1 Blockade Is Enhanced By Avadomide Immunotherapy through the Triggering of Immunogenic Interferon Signaling. Blood (2018) 132(Supplement 1):237-. doi: 10.1182/blood-201899-111605

199. Hus I, Salomon-Perzynski A, Robak T. The up-to-date role of biologics for the treatment of chronic lymphocytic leukemia. Expert Opin Biol Ther (2020) 20(7):799-812. doi: 10.1080/14712598.2020.1734557

200. Manshouri T, Do KA, Wang X, Giles FJ, O’Brien SM, Saffer H, et al. Circulating $\mathrm{CD} 20$ is detectable in the plasma of patients with chronic lymphocytic leukemia and is of prognostic significance. Blood (2003) 101 (7):2507-13. doi: 10.1182/blood-2002-06-1639

201. Vyas M, Schneider AC, Shatnyeva O, Reiners KS, Tawadros S, Kloess S, et al. Mono- and dual-targeting triplebodies activate natural killer cells and have 
anti-tumor activity in vitro and in vivo against chronic lymphocytic leukemia. Oncoimmunology (2016) 5(9):e1211220. doi: 10.1080/ 2162402X.2016.1211220

202. Qi J, Chen SS, Chiorazzi N, Rader C. An IgG1-like bispecific antibody targeting CD52 and CD20 for the treatment of B-cell malignancies. Methods (San Diego Calif) (2019) 154:70-6. doi: 10.1016/j.ymeth.2018.08.008

203. Fischer K, Bahlo J, Fink AM, Goede V, Herling CD, Cramer P, et al. Longterm remissions after FCR chemoimmunotherapy in previously untreated patients with CLL: updated results of the CLL8 trial. Blood (2016) 127 (2):208-15. doi: 10.1182/blood-2015-06-651125

204. Hallek M, Fischer K, Fingerle-Rowson G, Fink AM, Busch R, Mayer J, et al. Addition of rituximab to fludarabine and cyclophosphamide in patients with chronic lymphocytic leukaemia: a randomised, open-label, phase 3 trial. Lancet (London England) (2010) 376(9747):1164-74. doi: 10.1016/S01406736(10)61381-5

205. Eichhorst B, Fink AM, Bahlo J, Busch R, Kovacs G, Maurer C, et al. First-line chemoimmunotherapy with bendamustine and rituximab versus fludarabine, cyclophosphamide, and rituximab in patients with advanced chronic lymphocytic leukaemia (CLL10): an international, open-label, randomised, phase 3, non-inferiority trial. Lancet Oncol (2016) 17(7):92842. doi: 10.1016/S1470-2045(16)30051-1

206. Shanafelt TD, Wang V, Kay NE, Hanson CA, O'Brien SM, Barrientos JC, et al. A Randomized Phase III Study of Ibrutinib (PCI-32765)-Based Therapy Vs. Standard Fludarabine, Cyclophosphamide, and Rituximab (FCR) Chemoimmunotherapy in Untreated Younger Patients with Chronic Lymphocytic Leukemia (CLL): A Trial of the ECOG-ACRIN Cancer Research Group (E1912). Blood (2018) 132(Supplement 1):LBA-4-LBA-. doi: 10.1182/blood-2018-120779

207. Woyach JA, Ruppert AS, Heerema NA, Zhao W, Booth AM, Ding W, et al. Ibrutinib Regimens versus Chemoimmunotherapy in Older Patients with Untreated CLL. N Engl J Med (2018) 379(26):2517-28. doi: 10.1056/ NEJMoa1812836

208. Wu Y, Wang Y, Gu Y, Xia J, Kong X, Qian Q, et al. Safety and efficacy of Ofatumumab in chronic lymphocytic leukemia: a systematic review and meta-analysis. Hematol (Amsterdam Netherlands) (2017) 22(10):578-84. doi: $10.1080 / 10245332.2017 .1333974$

209. Casan JML, Wong J, Northcott MJ, Opat S. Anti-CD20 monoclonal antibodies: reviewing a revolution. Hum Vaccines Immunother (2018) 14 (12):2820-41. doi: 10.1080/21645515.2018.1508624

210. Al-Sawaf O, Fischer K, Engelke A, Pflug N, Hallek M, Goede V. Obinutuzumab in chronic lymphocytic leukemia: design, development and place in therapy. Drug Design Dev Ther (2017) 11:295-304. doi: 10.2147/ DDDT.S104869

211. Hillmen P, Robak T, Janssens A, Babu KG, Kloczko J, Grosicki S, et al. Chlorambucil plus ofatumumab versus chlorambucil alone in previously untreated patients with chronic lymphocytic leukaemia (COMPLEMENT 1): a randomised, multicentre, open-label phase 3 trial. Lancet (London England) (2015) 385(9980):1873-83. doi: 10.1016/S0140-6736(15)60027-7

212. Cortelezzi A, Sciumè M, Liberati AM, Vincenti D, Cuneo A, Reda G, et al. Bendamustine in combination with ofatumumab in relapsed or refractory chronic lymphocytic leukemia: a GIMEMA Multicenter Phase II Trial. Leukemia (2014) 28(3):642-8. doi: 10.1038/leu.2013.334

213. Jones JA, Robak T, Brown JR, Awan FT, Badoux X, Coutre S, et al. Efficacy and safety of idelalisib in combination with ofatumumab for previously treated chronic lymphocytic leukaemia: an open-label, randomised phase 3 trial. Lancet Haematol (2017) 4(3):e114-e26. doi: 10.1016/S2352-3026(17) 30019-4

214. Moreno C, Greil R, Demirkan F, Tedeschi A, Anz B, Larratt L, et al. Ibrutinib plus obinutuzumab versus chlorambucil plus obinutuzumab in first-line treatment of chronic lymphocytic leukaemia (iLLUMINATE): a multicentre, randomised, open-label, phase 3 trial. Lancet Oncol (2019) 20(1):43-56. doi: 10.1016/S1470-2045(18)30788-5

215. Sharman JP, Egyed M, Jurczak W, Skarbnik A, Pagel JM, Flinn IW, et al. Acalabrutinib with or without obinutuzumab versus chlorambucil and obinutuzmab for treatment-naive chronic lymphocytic leukaemia (ELEVATE TN): a randomised, controlled, phase 3 trial. Lancet (London England) (2020) 395(10232):1278-91. doi: 10.1016/S0140-6736 (20)30262-2
216. Fischer K, Al-Sawaf O, Bahlo J, Fink AM, Tandon M, Dixon M, et al. Venetoclax and Obinutuzumab in Patients with CLL and Coexisting Conditions. N Engl J Med (2019) 380(23):2225-36. doi: 10.1056/ NEJMoa1815281

217. Sawas A, Farber CM, Schreeder MT, Khalil MY, Mahadevan D, Deng C, et al. A phase 1/2 trial of ublituximab, a novel anti-CD20 monoclonal antibody, in patients with B-cell non-Hodgkin lymphoma or chronic lymphocytic leukaemia previously exposed to rituximab. Br J Haematol (2017) 177 (2):243-53. doi: 10.1111/bjh.14534

218. Lunning M, Vose J, Nastoupil L, Fowler N, Burger JA, Wierda WG, et al. Ublituximab and umbralisib in relapsed/refractory B-cell non-Hodgkin lymphoma and chronic lymphocytic leukemia. Blood (2019) 134(21):181120. doi: 10.1182/blood.2019002118

219. Nastoupil LJ, Lunning MA, Vose JM, Schreeder MT, Siddiqi T, Flowers CR, et al. Tolerability and activity of ublituximab, umbralisib, and ibrutinib in patients with chronic lymphocytic leukaemia and non-Hodgkin lymphoma: a phase 1 dose escalation and expansion trial. Lancet Haematol (2019) 6(2): e100-e9. doi: 10.1016/S2352-3026(18)30216-3

220. Scheuermann RH, Racila E. CD19 antigen in leukemia and lymphoma diagnosis and immunotherapy. Leukemia Lymphoma (1995) 18(5-6):38597. doi: $10.3109 / 10428199509059636$

221. Ohmachi K, Ogura M, Suehiro Y, Ando K, Uchida T, Choi I, et al. A multicenter phase I study of inebilizumab, a humanized anti-CD19 monoclonal antibody, in Japanese patients with relapsed or refractory Bcell lymphoma and multiple myeloma. Int J Hematol (2019) 109(6):657-64. doi: 10.1007/s12185-019-02635-9

222. Staber PB, Jurczak W, Brugger W, Chanan-Khan AA, Greil R, Hellmann A, et al. Primary Analysis of Anti-CD19 Tafasitamab (MOR208) Treatment in Combination with Idelalisib or Venetoclax in R/R CLL Patients Who Failed Prior BTK Inhibitor Therapy (COSMOS Trial). Blood (2019) 134 (Supplement_1):1754-. doi: 10.1182/blood-2019-128388

223. Robak T, Robak P. Anti-CD37 antibodies for chronic lymphocytic leukemia. Expert Opin Biol Ther (2014) 14(5):651-61. doi: 10.1517/ 14712598.2014 .890182

224. Robak T, Robak P, Smolewski P. TRU-016, a humanized anti-CD37 IgG fusion protein for the potential treatment of B-cell malignancies. Curr Opin Invest Drugs (London Engl 2000) (2009) 10(12):1383-90.

225. Byrd JC, Pagel JM, Awan FT, Forero A, Flinn IW, Deauna-Limayo DP, et al. A phase 1 study evaluating the safety and tolerability of otlertuzumab, an anti-CD37 mono-specific ADAPTIR therapeutic protein in chronic lymphocytic leukemia. Blood (2014) 123(9):1302-8. doi: 10.1182/blood2013-07-512137

226. Robak T, Hellmann A, Kloczko J, Loscertales J, Lech-Maranda E, Pagel JM, et al. Randomized phase 2 study of otlertuzumab and bendamustine versus bendamustine in patients with relapsed chronic lymphocytic leukaemia. $\mathrm{Br} J$ Haematol (2017) 176(4):618-28. doi: 10.1111/bjh.14464

227. Stilgenbauer S, Aurran Schleinitz T, Eichhorst B, Lang F, Offner F, Rossi JF, et al. Phase 1 first-in-human trial of the anti-CD37 antibody BI 836826 in relapsed/refractory chronic lymphocytic leukemia. Leukemia (2019) 33 (10):2531-5. doi: 10.1038/s41375-019-0475-z

228. Cui B, Ghia EM, Chen L, Rassenti LZ, DeBoever C, Widhopf GF,2, et al. High-level ROR1 associates with accelerated disease progression in chronic lymphocytic leukemia. Blood (2016) 128(25):2931-40. doi: 10.1182/blood2016-04-712562

229. Choi MY, Widhopf GF,2, EM G, RL K, MK H, Yu J, et al. Phase I Trial: Cirmtuzumab Inhibits ROR1 Signaling and Stemness Signatures in Patients with Chronic Lymphocytic Leukemia. Cell Stem Cell (2018) 22(6):951-9.e3. doi: 10.1016/j.stem.2018.05.018

230. Vyas M, Müller R, Pogge von Strandmann E. Antigen Loss Variants: Catching Hold of Escaping Foes. Front Immunol (2017) 8:175. doi: 10.3389/fimmu.2017.00175

231. Kontermann RE, Brinkmann U. Bispecific antibodies. Drug Discov Today (2015) 20(7):838-47. doi: 10.1016/j.drudis.2015.02.008

232. Goebeler ME, Bargou RC. T cell-engaging therapies - BiTEs and beyond. Nat Rev Clin Oncol (2020) 17(7):418-34. doi: 10.1038/s41571-020-0347-5

233. Topp MS, Gökbuget N, Stein AS, Zugmaier G, O’Brien S, Bargou RC, et al. Safety and activity of blinatumomab for adult patients with relapsed or refractory B-precursor acute lymphoblastic leukaemia: a multicentre, single- 
arm, phase 2 study. Lancet Oncol (2015) 16(1):57-66. doi: 10.1016/S14702045(14)71170-2

234. Wong R, Pepper C, Brennan P, Nagorsen D, Man S, Fegan C. Blinatumomab induces autologous T-cell killing of chronic lymphocytic leukemia cells. Haematologica (2013) 98(12):1930-8. doi: 10.3324/haematol.2012.082248

235. Goebeler ME, Knop S, Viardot A, Kufer P, Topp MS, Einsele H, et al. Bispecific T-Cell Engager (BiTE) Antibody Construct Blinatumomab for the Treatment of Patients With Relapsed/Refractory Non-Hodgkin Lymphoma: Final Results From a Phase I Study. J Clin Oncol (2016) 34(10):1104-11. doi: $10.1200 /$ JCO.2014.59.1586

236. Martens AWJ, Janssen SR, Derks IAM, Adams Iii HC, Izhak L, van Kampen R, et al. CD3xCD19 DART molecule treatment induces non-apoptotic killing and is efficient against high-risk chemotherapy and venetoclax-resistant chronic lymphocytic leukemia cells. J Immunother Cancer (2020) 8(1):e000218. doi: 10.1136/jitc-2019-000218

237. Liu L, Lam CK, Long V, Widjaja L, Yang Y, Li H, et al. MGD011, A CD19 x CD3 Dual-Affinity Retargeting Bi-specific Molecule Incorporating Extended Circulating Half-life for the Treatment of B-Cell Malignancies. Clin Cancer Res (2017) 23(6):1506-18. doi: 10.1158/1078-0432.CCR-16-0666

238. Robinson HR, Qi J, Cook EM, Nichols C, Dadashian EL, Underbayev C, et al. A CD19/CD3 bispecific antibody for effective immunotherapy of chronic lymphocytic leukemia in the ibrutinib era. Blood (2018) 132(5):521-32. doi: 10.1182/blood-2018-02-830992

239. Gohil SH, Evans R, Harasser M, El-Kholy M, Paredes-Moscosso SR, Della Peruta M, et al. Ibrutinib enhances the efficacy of ROR1 bispecific T cell engager mediated cytotoxicity in chronic lymphocytic leukaemia. $\mathrm{Br} J$ Haematol (2019) 186(2):380-2. doi: 10.1111/bjh.15911

240. Gleason MK, Verneris MR, Todhunter DA, Zhang B, McCullar V, Zhou SX, et al. Bispecific and trispecific killer cell engagers directly activate human NK cells through CD16 signaling and induce cytotoxicity and cytokine production. Mol Cancer Ther (2012) 11(12):2674-84. doi: 10.1158/15357163.MCT-12-0692

241. Kato K, Cantwell MJ, Sharma S, Kipps TJ. Gene transfer of CD40-ligand induces autologous immune recognition of chronic lymphocytic leukemia $B$ cells. J Clin Invest (1998) 101(5):1133-41. doi: 10.1172/JCI1472

242. Wierda WG, Castro JE, Aguillon R, Sampath D, Jalayer A, McMannis J, et al. A phase I study of immune gene therapy for patients with CLL using a membrane-stable, humanized CD154. Leukemia (2010) 24(11):1893-900. doi: 10.1038/leu.2010.191

243. Takahashi S, Rousseau RF, Yotnda P, Mei Z, Dotti G, Rill D, et al. Autologous antileukemic immune response induced by chronic lymphocytic leukemia $B$ cells expressing the CD40 ligand and interleukin 2 transgenes. Hum Gene Ther (2001) 12(6):659-70. doi: 10.1089/104303401300057360

244. Biagi E, Dotti G, Yvon E, Lee E, Pule M, Vigouroux S, et al. Molecular transfer of CD40 and OX40 ligands to leukemic human B cells induces expansion of autologous tumor-reactive cytotoxic T lymphocytes. Blood (2005) 105(6):2436-42. doi: 10.1182/blood-2004-07-2556

245. Zhu F, Khatri I, Spaner D, Gorczynski RM. An autologous tumor vaccine for CLL. Leukemia Res (2018) 68:40-7. doi: 10.1016/j.leukres.2018.03.002

246. Vantourout P, Hayday A. Six-of-the-best: unique contributions of $\gamma \delta \mathrm{T}$ cells to immunology. Nat Rev Immunol (2013) 13(2):88-100. doi: 10.1038/ nri3384

247. Correia DV, Lopes A, Silva-Santos B. Tumor cell recognition by $\gamma \delta \mathrm{T}$ lymphocytes: T-cell receptor vs. NK-cell receptors. Oncoimmunology (2013) 2(1):e22892. doi: 10.4161/onci.22892

248. Shifrin N, Raulet DH, Ardolino M. NK cell self tolerance, responsiveness and missing self recognition. Semin Immunol (2014) 26(2):138-44. doi: 10.1016/ j.smim.2014.02.007

249. Gross G, Waks T, Eshhar Z. Expression of immunoglobulin-T-cell receptor chimeric molecules as functional receptors with antibody-type specificity. Proc Natl Acad Sci U S A (1989) 86(24):10024-8. doi: 10.1073/ pnas.86.24.10024

250. Coscia M, Vitale C, Cerrano M, Maffini E, Giaccone L, Boccadoro M, et al. Adoptive immunotherapy with CAR modified $\mathrm{T}$ cells in cancer: current landscape and future perspectives. Front Biosci (Landmark ed) (2019) 24:1284-315. doi: 10.2741/4780

251. Cerrano M, Ruella M, Perales MA, Vitale C, Faraci DG, Giaccone L, et al. The Advent of CAR T-Cell Therapy for Lymphoproliferative Neoplasms:
Integrating Research Into Clinical Practice. Front Immunol (2020) 11:888. doi: $10.3389 /$ fimmu.2020.00888

252. Vitale C, Strati P. CAR T-Cell Therapy for B-Cell non-Hodgkin Lymphoma and Chronic Lymphocytic Leukemia: Clinical Trials and Real-World Experiences. Front Oncol (2020) 10:849. doi: 10.3389/fonc.2020.00849

253. Kalos M, Levine BL, Porter DL, Katz S, Grupp SA, Bagg A, et al. T cells with chimeric antigen receptors have potent antitumor effects and can establish memory in patients with advanced leukemia. Sci Transl Med (2011) 3 (95):95ra73. doi: 10.1126/scitranslmed.3002842

254. Porter DL, Hwang WT, Frey NV, Lacey SF, Shaw PA, Loren AW, et al. Chimeric antigen receptor $T$ cells persist and induce sustained remissions in relapsed refractory chronic lymphocytic leukemia. Sci Transl Med (2015) 7 (303):303ra139. doi: 10.1126/scitranslmed.aac5415

255. Kochenderfer JN, Dudley ME, Feldman SA, Wilson WH, Spaner DE, Maric I, et al. B-cell depletion and remissions of malignancy along with cytokineassociated toxicity in a clinical trial of anti-CD19 chimeric-antigen-receptortransduced T cells. Blood (2012) 119(12):2709-20. doi: 10.1182/blood-201110-384388

256. Kochenderfer JN, Dudley ME, Kassim SH, Somerville RP, Carpenter RO, Stetler-Stevenson $\mathrm{M}$, et al. Chemotherapy-refractory diffuse large B-cell lymphoma and indolent B-cell malignancies can be effectively treated with autologous T cells expressing an anti-CD19 chimeric antigen receptor. J Clin Oncol (2015) 33(6):540-9. doi: 10.1200/JCO.2014.56.2025

257. Cruz CR, Micklethwaite KP, Savoldo B, Ramos CA, Lam S, Ku S, et al. Infusion of donor-derived CD19-redirected virus-specific $\mathrm{T}$ cells for B-cell malignancies relapsed after allogeneic stem cell transplant: a phase 1 study. Blood (2013) 122(17):2965-73. doi: 10.1182/blood-2013-06-506741

258. Fraietta JA, Beckwith KA, Patel PR, Ruella M, Zheng Z, Barrett DM, et al. Ibrutinib enhances chimeric antigen receptor T-cell engraftment and efficacy in leukemia. Blood (2016) 127(9):1117-27. doi: 10.1182/blood-2015-11679134

259. Ramos CA, Savoldo B, Torrano V, Ballard B, Zhang H, Dakhova O, et al. Clinical responses with $\mathrm{T}$ lymphocytes targeting malignancy-associated $\mathrm{\kappa}$ light chains. J Clin Invest (2016) 126(7):2588-96. doi: 10.1172/JCI86000

260. Brudno JN, Somerville RP, Shi V, Rose JJ, Halverson DC, Fowler DH, et al. Allogeneic T Cells That Express an Anti-CD19 Chimeric Antigen Receptor Induce Remissions of B-Cell Malignancies That Progress After Allogeneic Hematopoietic Stem-Cell Transplantation Without Causing Graft-VersusHost Disease. J Clin Oncol (2016) 34(10):1112-21. doi: 10.1200/ JCO.2015.64.5929

261. Turtle CJ, Hanafi L-A, Berger C, Gooley T, Chaney C, Cherian S, et al. Rate of durable complete response in ALL, NHL, and CLL after immunotherapy with optimized lymphodepletion and defined composition CD19 CAR-T cells. J Clin Oncol (2016) 34(15_suppl):102-. doi: 10.1200/ JCO.2016.34.15_suppl.102

262. Turtle CJ, Hay KA, Hanafi LA, Li D, Cherian S, Chen X, et al. Durable Molecular Remissions in Chronic Lymphocytic Leukemia Treated With CD19-Specific Chimeric Antigen Receptor-Modified T Cells After Failure of Ibrutinib. J Clin Oncol (2017) 35(26):3010-20. doi: 10.1200/ JCO.2017.72.8519

263. Geyer MB, Rivière I, Sénéchal B, Wang X, Wang Y, Purdon TJ, et al. Autologous CD19-Targeted CAR T Cells in Patients with Residual CLL following Initial Purine Analog-Based Therapy. Mol Ther J Am Soc Gene Ther (2018) 26(8):1896-905. doi: 10.1016/j.ymthe.2018.05.018

264. Enblad G, Karlsson H, Gammelgård G, Wenthe J, Lövgren T, Amini RM, et al. A Phase I/IIa Trial Using CD19-Targeted Third-Generation CAR T Cells for Lymphoma and Leukemia. Clin Cancer Res (2018) 24(24):6185-94. doi: 10.1158/1078-0432.CCR-18-0426

265. Ramos CA, Rouce R, Robertson CS, Reyna A, Narala N, Vyas G, et al. In Vivo Fate and Activity of Second- versus Third-Generation CD19-Specific CAR-T Cells in B Cell Non-Hodgkin's Lymphomas. Mol Ther J Am Soc Gene Ther (2018) 26(12):2727-37. doi: 10.1016/j.ymthe.2018.09.009

266. Siddiqi T, Soumerai JD, Wierda WG, Dubovsky JA, Gillenwater HH, Gong L, et al. Rapid MRD-Negative Responses in Patients with Relapsed/Refractory CLL Treated with Liso-Cel, a CD19-Directed CAR T-Cell Product: Preliminary Results from Transcend CLL 004, a Phase 1/2 Study Including Patients with High-Risk Disease Previously Treated with Ibrutinib. Blood (2018) 132(Supplement 1):300-. doi: 10.1182/blood-2018-99-110462 
267. Siddiqi T, Soumerai JD, Dorritie KA, Stephens DM, Riedell PA, Arnason JE, et al. (uMRD) Responses in Patients with Relapsed/Refractory (R/R) Chronic Lymphocytic Leukemia/Small Lymphocytic Lymphoma (CLL/SLL) Treated with Lisocabtagene Maraleucel (liso-cel), a CD19-Directed CAR T Cell Product: Updated Results from Transcend CLL 004, a Phase 1/2 Study Including Patients with High-Risk Disease Previously Treated with Ibrutinib. Blood (2019) 134(Supplement_1):503-. doi: 10.1182/blood-2019-127603

268. Delgado J, Caballero-Baños M, Ortiz-Maldonado V, Castellà M, Magnano L, Juan M, et al. Chimeric Antigen Receptor T Cells Targeting CD19 and Ibrutinib for Chronic Lymphocytic Leukemia. HemaSphere (2019) 3(2):e174. doi: 10.1097/HS9.0000000000000174

269. Brentjens RJ, Rivière I, Park JH, Davila ML, Wang X, Stefanski J, et al. Safety and persistence of adoptively transferred autologous CD19-targeted $\mathrm{T}$ cells in patients with relapsed or chemotherapy refractory B-cell leukemias. Blood (2011) 118(18):4817-28. doi: 10.1182/blood-2011-04-348540

270. Geyer MB, Rivière I, Sénéchal B, Wang X, Wang Y, Purdon TJ, et al. Safety and tolerability of conditioning chemotherapy followed by CD19-targeted CAR T cells for relapsed/refractory CLL. JCI Insight (2019) 5(9):e122627. doi: $10.1172 /$ jci.insight. 122627

271. Schubert M-L, Schmitt A, Neuber B, Hückelhoven-Krauss A, Kunz A, Wang L, et al. Third-Generation CAR T Cells Targeting CD19 Are Associated with an Excellent Safety Profile and Might Improve Persistence of CAR T Cells in Treated Patients. Blood (2019) 134(Supplement_1):51-. doi: 10.1182/blood-2019-125423

272. Batlevi CL, Palomba ML, Park J, Mead E, Santomasso B, Riviere I, et al. PHASE I CLINICAL TRIAL OF CD19-TARGETED 19-28Z/4-1BBL “ARMORED” CAR T CELLS IN PATIENTS WITH RELAPSED OR REFRACTORY NHL AND CLL INCLUDING RICHTER TRANSFORMATION. Hematol Oncol (2019) 37 (S2):166-7. doi: 10.1002/hon.124_2629

273. Shah NN, Zhu F, Schneider D, Taylor C, Krueger W, Worden A, et al. Results of a phase I study of bispecific anti-CD19, anti-CD20 chimeric antigen receptor (CAR) modified $\mathrm{T}$ cells for relapsed, refractory, non-Hodgkin lymphoma. J Clin Oncol (2019) 37(15_suppl):2510-. doi: 10.1200/ JCO.2019.37.15_suppl.2510

274. Liu E, Marin D, Banerjee P, Macapinlac HA, Thompson P, Basar R, et al. Use of CAR-Transduced Natural Killer Cells in CD19-Positive Lymphoid Tumors. N Engl J Med (2020) 382(6):545-53. doi: 10.1056/NEJMoa1910607

275. Fraietta JA, Lacey SF, Orlando EJ, Pruteanu-Malinici I, Gohil M, Lundh S, et al. Determinants of response and resistance to CD19 chimeric antigen receptor (CAR) T cell therapy of chronic lymphocytic leukemia. Nat Med (2018) 24(5):563-71. doi: 10.1038/s41591-018-0010-1

276. Qin JS, Johnstone TG, Baturevych A, Hause RJ, Ragan SP, Clouser CR, et al. Antitumor Potency of an Anti-CD19 Chimeric Antigen Receptor T-Cell Therapy, Lisocabtagene Maraleucel in Combination With Ibrutinib or Acalabrutinib. J Immunother (Hagerstown Md 1997) (2020) 43(4):107-20. doi: 10.1097/CJI.0000000000000307

277. Herrera L, Santos S, Vesga MA, Anguita J, Martin-Ruiz I, Carrascosa T, et al. Adult peripheral blood and umbilical cord blood NK cells are good sources for effective CAR therapy against CD19 positive leukemic cells. Sci Rep (2019) 9(1):18729. doi: 10.1038/s41598-019-55239-y

278. Suck G, Odendahl M, Nowakowska P, Seidl C, Wels WS, Klingemann HG, et al. NK-92: an 'off-the-shelf therapeutic' for adoptive natural killer cellbased cancer immunotherapy. Cancer Immunol Immunother CII (2016) 65 (4):485-92. doi: 10.1007/s00262-015-1761-x

279. Jacoby E, Yang Y, Qin H, Chien CD, Kochenderfer JN, Fry TJ. Murine allogeneic CD19 CAR T cells harbor potent antileukemic activity but have the potential to mediate lethal GVHD. Blood (2016) 127(10):1361-70. doi: 10.1182/blood-2015-08-664250

280. Shah N, Li L, McCarty J, Kaur I, Yvon E, Shaim H, et al. Phase I study of cord blood-derived natural killer cells combined with autologous stem cell transplantation in multiple myeloma. Br J Haematol (2017) 177(3):457-66. doi: 10.1111/bih.14570

281. Liu E, Tong Y, Dotti G, Shaim H, Savoldo B, Mukherjee M, et al. Cord blood NK cells engineered to express IL-15 and a CD19-targeted CAR show longterm persistence and potent antitumor activity. Leukemia (2018) 32(2):52031. doi: $10.1038 /$ leu.2017.226

282. He X, Xu C. Immune checkpoint signaling and cancer immunotherapy. Cell Res (2020) 30(8):660-9. doi: 10.1038/s41422-020-0343-4
283. McClanahan F, Hanna B, Miller S, Clear AJ, Lichter P, Gribben JG, et al. PDL1 checkpoint blockade prevents immune dysfunction and leukemia development in a mouse model of chronic lymphocytic leukemia. Blood (2015) 126(2):203-11. doi: 10.1182/blood-2015-01-622936

284. Wierz M, Pierson S, Guyonnet L, Viry E, Lequeux A, Oudin A, et al. Dual PD1/LAG3 immune checkpoint blockade limits tumor development in a murine model of chronic lymphocytic leukemia. Blood (2018) 131(14):161721. doi: 10.1182/blood-2017-06-792267

285. Ding W, LaPlant BR, Call TG, Parikh SA, Leis JF, He R, et al. Pembrolizumab in patients with CLL and Richter transformation or with relapsed CLL. Blood (2017) 129(26):3419-27.

286. Jain N, Basu S, Thompson PA, Ohanian M, Ferrajoli A, Pemmaraju N, et al. Nivolumab Combined with Ibrutinib for CLL and Richter Transformation: A Phase II Trial. Blood (2016) 128(22):59-. doi: 10.1182/blood.V128.22.59.59

287. Berger R, Rotem-Yehudar R, Slama G, Landes S, Kneller A, Leiba M, et al. Phase I safety and pharmacokinetic study of CT-011, a humanized antibody interacting with PD-1, in patients with advanced hematologic malignancies. Clin Cancer Res (2008) 14(10):3044-51. doi: 10.1158/1078-0432.CCR-074079

288. Mahadevan D, Lanasa MC, Farber C, Pandey M, Whelden M, Faas SJ, et al. Phase I study of samalizumab in chronic lymphocytic leukemia and multiple myeloma: blockade of the immune checkpoint CD200. J Immunother Cancer (2019) 7(1):227. doi: 10.1186/s40425-019-0710-1

289. Younes A, Brody J, Carpio C, Lopez-Guillermo A, Ben-Yehuda D, Ferhanoglu B, et al. Safety and activity of ibrutinib in combination with nivolumab in patients with relapsed non-Hodgkin lymphoma or chronic lymphocytic leukaemia: a phase 1/2a study. Lancet Haematol (2019) 6(2): e67-78. doi: 10.1016/S2352-3026(18)30217-5

290. Mato AR, Svoboda J, Luning Prak ET, Schuster SJ, Tsao P, Dorsey C, et al. Phase I/II Study of Umbralisib (TGR-1202) in Combination with Ublituximab (TG-1101) and Pembrolizumab in Patients with Relapsed/ Refractory CLL and Richter's Transformation. Blood (2018) 132 (Supplement 1):297-. doi: 10.1182/blood-2018-99-117526

291. Rogers KA, Huang Y, Dotson E, Lundberg J, Andritsos LA, Awan FT, et al. Use of PD-1 (PDCD1) inhibitors for the treatment of Richter syndrome: experience at a single academic centre. Br J Haematol (2019) 185(2):363-6. doi: 10.1111/bjh.15508

292. Khouri IF, Fernandez Curbelo I, Turturro F, Jabbour EJ, Milton DR, Bassett RL Jr., et al. Ipilimumab plus Lenalidomide after Allogeneic and Autologous Stem Cell Transplantation for Patients with Lymphoid Malignancies. Clin Cancer Res (2018) 24(5):1011-8. doi: 10.1158/1078-0432.CCR-17-2777

293. Davids MS, Kim HT, Costello C, Herrera AF, Locke FL, Maegawa RO, et al. A multicenter phase 1 study of nivolumab for relapsed hematologic malignancies after allogeneic transplantation. Blood (2020) 135(24):218291. doi: 10.1182/blood.2019004710

Conflict of Interest: MB has received honoraria from Sanofi, Celgene, Amgen, Janssen, Novartis, Bristol-Myers Squibb, and AbbVie; has served on the advisory boards for Janssen and GSK; has received research funding from Sanofi, Celgene, Amgen, Janssen, Novartis, Bristol-Myers Squibb, and Mundipharma. CV has received consultancy fees from Janssen. MC received honoraria from Janssen, Gilead, Abbvie, Shire and research support from Janssen and Karyopharm Therapeutics.

The remaining authors declare that the research was conducted in the absence of any commercial or financial relationships that could be construed as a potential conflict of interest.

The reviewer AK declared a past co-authorship with several of the authors CV and MC to the handling editor.

Copyright (๑) 2020 Griggio, Perutelli, Salvetti, Boccellato, Boccadoro, Vitale and Coscia. This is an open-access article distributed under the terms of the Creative Commons Attribution License (CC BY). The use, distribution or reproduction in other forums is permitted, provided the original author(s) and the copyright owner(s) are credited and that the original publication in this journal is cited, in accordance with accepted academic practice. No use, distribution or reproduction is permitted which does not comply with these terms. 